\title{
Article \\ Carbon, Nitrogen and Water Footprints of Organic Rice and Conventional Rice Production over 4 Years of Cultivation: A Case Study in the Lower North of Thailand
}

\author{
Noppol Arunrat ${ }^{1, *}$, Sukanya Sereenonchai ${ }^{1}$, Winai Chaowiwat ${ }^{2}$, Can Wang ${ }^{3,4}$ and Ryusuke Hatano ${ }^{5}$ \\ 1 Faculty of Environment and Resource Studies, Mahidol University, Nakhon Pathom 73170, Thailand; \\ sukanya.ser@mahidol.ac.th \\ 2 Hydro-Informatics Innovation Division, Hydro Informatics Institute, Bangkok 10400, Thailand; \\ winai@haii.or.th \\ 3 State Key Joint Laboratory of Environment Simulation and Pollution Control (SKLESPC), \\ School of Environment, Tsinghua University, Beijing 100084, China; canwang@tsinghua.edu.cn \\ 4 Tsinghua-Rio Tinto Joint Research Centre for Resources, Energy and Sustainable Development, \\ Beijing 100084, China \\ 5 Laboratory of Soil Science, Graduate School of Agriculture, Hokkaido University, Sapporo 060-8589, Japan; \\ hatano@chem.agr.hokudai.ac.jp \\ * Correspondence: noppol.aru@mahidol.ac.th
}

check for updates

Citation: Arunrat, N.; Sereenonchai, S.; Chaowiwat, W.; Wang, C.; Hatano,

R. Carbon, Nitrogen and Water

Footprints of Organic Rice and

Conventional Rice Production over 4 Years of Cultivation: A Case Study in the Lower North of Thailand. Agronomy 2022, 12, 380. https:// doi.org/10.3390/agronomy12020380

Academic Editors: David Pérez-Neira, Gabrijel Ondrasek, Marta Soler-Montiel, Simón Xavier and Stephan M. Haefele

Received: 11 December 2021

Accepted: 1 February 2022

Published: 3 February 2022

Publisher's Note: MDPI stays neutral with regard to jurisdictional claims in published maps and institutional affiliations.

Copyright: (C) 2022 by the authors. Licensee MDPI, Basel, Switzerland. This article is an open access article distributed under the terms and conditions of the Creative Commons Attribution (CC BY) license (https:// creativecommons.org/licenses/by/ $4.0 /)$.

\begin{abstract}
An integrated method is required for comprehensive assessment of the environmental impacts and economic benefits of rice production systems. Therefore, the objective of this study was to apply different footprinting approaches (carbon footprint (CF), nitrogen footprint (NF), water footprint (WF)) and determine the economic return on organic rice farming $(\mathrm{OF})$ and conventional rice farming (CVF) at the farm scale. Over the 4-year study period (2018-2021), the results showed lower net greenhouse gas (GHG) emissions in OF (3289.1 kg CO $\mathrm{CO} \mathrm{ha}^{-1}$ year $^{-1}$ ) than in CVF (4921.7 $\mathrm{kg} \mathrm{CO}_{2} \mathrm{eq} \mathrm{ha}^{-1}$ year $^{-1}$ ), indicating that the use of OF can mitigate the GHG emissions from soil carbon sequestration. However, there was a higher $\mathrm{CF}$ intensity in $\mathrm{OF}\left(1.17 \mathrm{~kg} \mathrm{CO}_{2} \mathrm{eq} \mathrm{kg}^{-1}\right.$ rice yield) than in CVF (0.93 $\mathrm{kg} \mathrm{CO}_{2} \mathrm{eq} \mathrm{kg}^{-1}$ rice yield) due to the lower yield. The NF intensities of OF and CVF were 0.34 and $11.94 \mathrm{~kg} \mathrm{Neq} \mathrm{kg}^{-1}$ rice yield, respectively. The total WF of CVF $\left(1470.1 \mathrm{~m}^{3} \mathrm{ton}^{-1}\right)$ was higher than that in OF $\left(1216.3 \mathrm{~m}^{3}\right.$ ton $\left.^{-1}\right)$. The gray water in CVF was significantly higher than that in OF due to the use of chemical fertilizers, herbicides, and pesticides. Although the rice yield in OF was nearly two times lower than that in CVF, the economic return was higher due to lower production costs and higher rice prices. However, more field studies and long-term monitoring are needed for future research.
\end{abstract}

Keywords: carbon footprint; nitrogen footprint; water footprint; soil organic carbon; rice paddy

\section{Introduction}

With approximately $10-12 \%$ in carbon dioxide equivalents $\left(\mathrm{CO}_{2} \mathrm{eq}\right)$, agriculture-mainly rice cultivation - is part of global greenhouse gas (GHG) emissions and is a major anthropogenic source of atmospheric methane $\left(\mathrm{CH}_{4}\right)$ [1,2]. Global fertilizer usage has increased from 32 to $106 \mathrm{Mt} \mathrm{year}^{-1}$ (+331\%) since the Green Revolution in the 1950s, leading to an increase in nitrous oxide $\left(\mathrm{N}_{2} \mathrm{O}\right)$ emissions since then. Moreover, farming activities contribute to carbon dioxide $\left(\mathrm{CO}_{2}\right)$ emission in the field from the use of fossil fuels [2]. Thus, GHG emissions from the agricultural sector are a non-negligible part of global warming that has caused serious environmental problems.

Thailand is one of the world's major producers and exporters of rice (Oryza sativa L.) and was ranked as the sixth-largest rice producer in the world, producing about 25.31 million tons in the 2020/2021 season [3]. As reported in several studies (e.g., Ding et al. [4]; Pandey and Agrawal, [5]; Arunrat et al. [6]; Maraseni et al. [7]), rice cultivation 
requires continuous flooding, which causes an anerobic condition in paddy fields, leading to $\mathrm{CH}_{4}$ generation by methanogenic bacteria. Nitrogen fertilizer is commonly used in conventional rice farming (CVF) to enhance plant growth and increase rice yield. Farming activities (e.g., transportation, tillage, planting, spraying, water pumping, and harvesting) involve using fossil fuels that generate $\mathrm{CO}_{2}$ from combustion. After harvest, rice straw and stubble are left on the ground to decay or burned to ashes and are thus likely to produce $\mathrm{CH}_{4}, \mathrm{~N}_{2} \mathrm{O}$, and $\mathrm{CO}_{2}$. Organic rice farming $(\mathrm{OF})$ has been promoted in many counties. This is because it stores more carbon in the soil, using no synthetic fertilizers, pesticides, and herbicides as well as avoiding rice residue burning, leading to net GHG emission reduction compared with CVF $[8,9]$. However, most studies have shown a lower average yield in OF than in CVF [10-12]. Moreover, rice production always requires water, whether as rainfall, irrigation, or groundwater, while water scarcity requires consideration of water-use efficiency and the maintenance of water quality [13]; yet the comparison between OF and CVF is still limited. Beyond the abovementioned issues, rice cultivation is closely linked to farmers' income, which means a reduction in their incomes can negatively affect their livelihoods, especially if the low yield in OF would generate lower income compared with CVF. When considering these challenges, the need for an integrated assessment of rice production is crucial. Sustainable management should consider the environmental impact of GHG emissions while emphasizing water use efficiency, and the economic benefits should not be ignored.

In seeking sustainable management and combatting climate change, the "footprint family" could be beneficial for integrated assessment indicators. The carbon footprint (CF), water footprint (WF), and nitrogen footprint (NF) have been developed to understand how human activities exert pressure on the environment. The $\mathrm{CF}$ is expressed as a quantity of $\mathrm{CO}_{2} \mathrm{eq}$, which corresponds to the sum of each GHG contribution to global warming [14]. The WF is an indicator for measuring the volume of direct and indirect water use in the life cycle of a product, consisting of green, blue, and gray WFs [15]. Green WF refers to the amount of rainwater that is stored in the soil and evaporated, transpired, or consumed by plants during cultivation. Blue WF indicates the consumption of water from rivers, lakes, and groundwater, and gray WF represents the consumption of freshwater to assimilate a load of pollutants and meet water quality standards [16-19]. In addition, the NF is a new footprint concept that was introduced after the concepts of ecological footprint, $\mathrm{CF}$, and WF. The NF was developed to quantitatively assess the influence of human production and lifestyle on reactive nitrogen $(\mathrm{Nr})$, all nitrogen species $\left(\mathrm{N}_{2} \mathrm{O}\right.$, ammonia $\left[\mathrm{NH}_{3}\right]$ volatilization, and nitrate leaching) except $\mathrm{N}_{2}$ emissions to the environment per ton of products [20-22].

Soils have the potential to reduce the increase in the atmospheric $\mathrm{CO}_{2}$ concentration by capturing $\mathrm{CO}_{2}$ into plants and soil [23]. Rice fields have been reported as a high potential source of soil carbon sequestration $[24,25]$ via incorporation of crop residues, direct manure and compost application, growing crop rotation, minimum/no tillage, and application of organic fertilizers $[24,26,27]$. These have led to increased attention on OF, motivated by the expected lower risks from negligible chemical inputs and reduction in net GHG emissions $[12,28]$. The number of $\mathrm{OF}$ and cultivation areas are quite small due to the lower average yield obtained than when using synthetic fertilizers, pesticides, and herbicides, but OF has lower production costs than CVF. Reganold and Wachter [10] and Willer et al. [29] reported that around $1 \%$ of global agricultural area is covered by organic farms, and this figure rises to slightly $>1 \%$ in several developed countries. In Thailand, there is a project to promote organic rice production for 160,000 ha during 2017-2021 and help farmers obtain the organic rice standard from the Ministry of Agriculture and Cooperatives. Although the goal of 160,000 ha of organic rice represents approximately $2 \%$ of the total rice cultivation area in Thailand [30], it indicates an increase in the total organic rice area compared to the past few years. Thus, the development of a rice production system with low environmental impacts and high agronomic benefits is needed, and a new integrated method of comprehensive assessment should be adopted. However, there is limited research considering more than two members of the footprint family for rice 
production in combination with an economic perspective. Therefore, the objective of this study was to apply the different footprinting approaches $(\mathrm{CF}, \mathrm{NF}, \mathrm{WF})$ and determine the economic return on $\mathrm{OF}$ and $\mathrm{CVF}$ at the farm scale.

\section{Materials and Methods}

\subsection{Study Sites}

Soil organic carbon (SOC) sequestration was not considered in CF estimation by many studies due to a lack of data and the requirement for long-term investigation. Meanwhile, several studies $[23,31-34]$ have asserted that accounting for SOC sequestration in the CF estimation can increase the accuracy of the net $\mathrm{CF}$ estimation, which supports effective policy and individual decision-making to reduce GHG emissions or sequester more carbon. Therefore, SOC sequestration was accounted in the present study, which added important insights into the estimation of the $\mathrm{CF}$ of rice production.

Both organic and conventional rice farming were conducted in the farmer's field over 4 years of cultivation (2018-2021) to reduce the uncertainty of data. These fields were good representatives under identical soil texture and differed only in the management practices of typical conventional and organic systems. Furthermore, conducting the study in the farmer's own fields and allowing them to manage all farming practices in the usual way provided a realistic view of the farmer's management practices. Thus, the organic rice farm (wet rice farming) at the Samnak Khun Nen Subdistrict, Dong Charoen District, Phichit province was monitored and the data collected there $\left(16^{\circ} 04^{\prime} 04.1^{\prime \prime} \mathrm{N}, 100^{\circ} 32^{\prime} 31.1^{\prime \prime}\right.$ E, Figure 1). This farm has been producing organic rice for more than 10 years and was first certified by the International Federation of Organic Agriculture Movements (IFOAM) in 2016 and EU/USDA Organic Standards in 2018. The farmer grows the "Riceberry" rice variety once a year from August to December (120 days). For a fair comparison, a conventional rice farm (wet rice farming) $\left(16^{\circ} 04^{\prime} 04.5^{\prime \prime} \mathrm{N}, 100^{\circ} 32^{\prime} 29.8^{\prime \prime} \mathrm{E}\right)$ was monitored and investigated as the comparison site (Figure 1). This farm can also grow rice once a year (from August to November) by choosing the "RD41" (105 days), "RD57" (110 days), or "RD79" (115 days) rice varieties.

According to the IFOAM and EU/USDA organic regulations, a buffer zone sufficient to prevent contamination from adjacent areas must be present. In this study site, sugarcane was planted as a $2 \mathrm{~m}$-wide buffer zone to prevent contact with prohibited substances applied to the conventional field. The water sources used on an organic farm must be free of contaminants from natural, irrigated, and non-organic fields, so the organic farm must be built with a farm pond to store the water before it drains into the organic field (Figure 1).

\subsection{Data Collection}

\subsubsection{Farm Management Practice Data}

Data on farm management practices in four crop years (2017/2018-2020/2021) were obtained from the owner of organic rice and conventional rice farms. The farmers were requested to record all management practices throughout the crop year of rice production in personal notebooks. The quantities of agricultural inputs were recorded, including rice seeds, organic materials, chemical fertilizers, insecticides, herbicides, diesel and gasoline fuels, transportation (type of vehicle, distance, and fossil fuel used), harvest, paddy rice yield, and post-harvest. Moreover, the exact dates and months of all activities (land preparation, sowing, transplanting, applying chemical fertilizers, insecticides, herbicides, and bio-fermented juice, water pumping, and harvesting) were recorded and collected.

\subsubsection{Soil Sampling and Analysis}

Soil was sampled from both farms at $0-30 \mathrm{~cm}$ depth after the harvest in four consecutive years (2018-2021). At each farm, soil samples were randomly gathered from five pits. At each pit, soil samples were collected in three replications. The soil bulk density was taken using a soil core $(5.0 \mathrm{~cm}$ width $\times 5.5 \mathrm{~cm}$ length) and was then measured after 
drying in an oven at $105^{\circ} \mathrm{C}$ for $24 \mathrm{~h}$. All soil samples were air dried at room temperature for 7 days; then, they were crushed and passed through a $2 \mathrm{~mm}$ sieve.

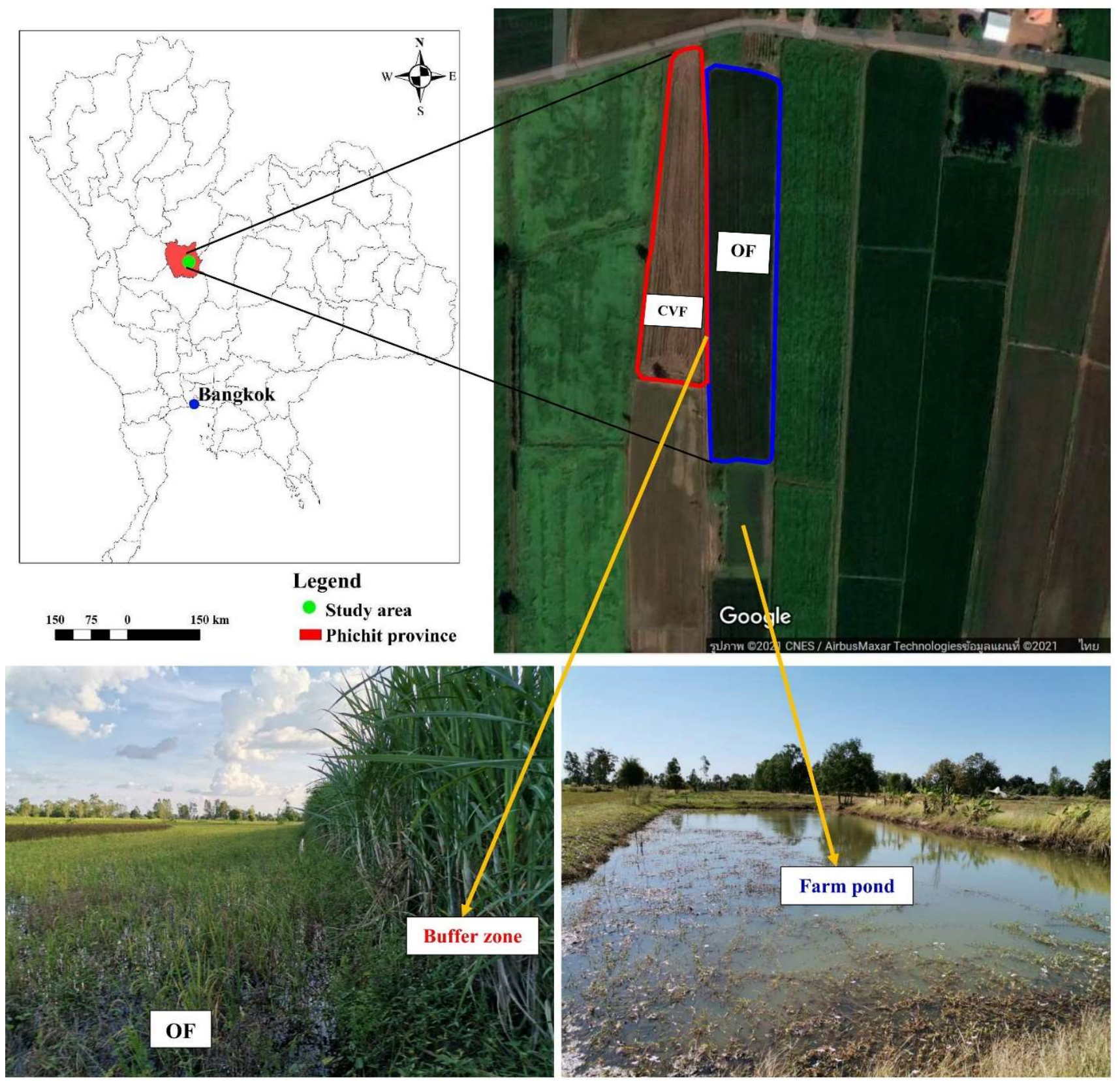

Figure 1. Study area of an organic rice farm (OF) and a conventional rice farm (CVF). The aerial image was taken from Google maps on 30 May 2021. The photos were taken on 29 August 2021 by Noppol Arunrat.

Soil particles size (soil texture) was determined by using a hydrometer. The electrical conductivity (ECe) was determined by using an EC meter following preparation of the saturated soil extracts (1:5) [35]. Soil pH was measured in a 1:1 soil-to-water mixture using a pH meter [36]. The molybdate blue method (Bray II extraction) was used to analyze the available phosphorus (Avail. P) [37]. The available potassium (Avail. K), calcium (Avail. $\mathrm{Ca}$ ), and magnesium (Avail. $\mathrm{Mg}$ ) were determined by atomic absorption spectrometry ( $\mathrm{NH}_{4} \mathrm{OAc}$ extraction) [38]. Organic carbon (OC) was analyzed following the description of Walkley and Black [39]. 


\subsubsection{Soil Organic Carbon Calculation}

Equations (1) and (2) were used to calculate the SOC stock.

$$
\begin{aligned}
\mathrm{SOC}_{30 \mathrm{~cm}} & =(\varphi \times \mathrm{OC} \times \mathrm{L}) \times 1000 \\
\Delta \mathrm{SOCS}_{30 \mathrm{~cm}} & =\frac{\mathrm{SOCS}_{2021}-\mathrm{SOCS}_{2018}}{3} \times \frac{44}{12}
\end{aligned}
$$

where $\mathrm{SOC}_{30 \mathrm{~cm}}$ is soil organic carbon stock $\left(\mathrm{kg} \mathrm{C} \mathrm{ha}^{-1}\right) ; \varphi$ is soil bulk density $\left(\mathrm{g} \mathrm{cm}^{-3}\right)$; OC is organic carbon content (\%); $\mathrm{L}$ is soil thickness $(\mathrm{cm}) ; \mathrm{SOCS}_{30 \mathrm{~cm}}$ is the annual amount of SOC at a depth of $30 \mathrm{~cm}\left(\mathrm{~kg} \mathrm{CO}_{2} \mathrm{eq} \mathrm{ha}{ }^{-1}\right.$ year $\left.{ }^{-1}\right) ; \mathrm{SOCS}_{2021}$ and $\mathrm{SOCS}_{2018}$ are the amounts of SOC stock ( $\left.\mathrm{kg} \mathrm{C} \mathrm{ha}^{-1}\right)$ in 2021 and 2018, respectively, $30 \mathrm{~cm}$ is the total soil depth in this study, and $44 / 12$ is the coefficient for converting $\mathrm{C}$ into $\mathrm{CO}_{2}$.

In this study, the soil thickness $(\mathrm{cm})$ was adjusted by using the equivalent soil mass method to reduce the error in carbon stock calculation due to farming activities over time. The soil mass values at the beginning were in 2018, and at the end, they were in the year 2021. The equation is presented below [40]:

$$
\text { Soil mass }=\varphi \times \mathrm{L}
$$

where soil mass is the mass of soil sample $\left(\mathrm{kg}\right.$ soil $\left.\mathrm{m}^{-2}\right)$. After determining soil thickness, the SOC stock was calculated using Equations (1) and (2), respectively, to obtain the equivalent soil mass.

\subsection{System Boundary and Functional Unit}

The CF and NF were calculated based on the 2019 Refinement to the 2006 IPCC Guidelines for National Greenhouse Gas Inventories [41]. Moreover, the life cycle assessment of products from the cradle to the gate was used and considered in four stages: raw material production, transportation, field emissions, and harvesting (Figure 2). The $\mathrm{CO}_{2}, \mathrm{CH}_{4}$, and $\mathrm{N}_{2} \mathrm{O}$ emissions were expressed in the form of $\mathrm{CO}_{2} \mathrm{eq}$. The radiative forcing potential relative to $\mathrm{CO}_{2}$ was 28 for $\mathrm{CH}_{4}$ and 265 for $\mathrm{N}_{2} \mathrm{O}$ [42]. Meanwhile, the NF was considered $\mathrm{NH}_{3}$ volatilization, $\mathrm{N}_{2} \mathrm{O}$ emission, $\mathrm{NO}_{3}^{-}$and $\mathrm{NH}_{4}^{+}$leaching. The functional unit of $\mathrm{CF}$ is expressed as $\mathrm{kg} \mathrm{CO}_{2} \mathrm{eq} \mathrm{ha}{ }^{-1}$ year ${ }^{-1}$ and $\mathrm{kg} \mathrm{CO}_{2} \mathrm{eq} \mathrm{kg}^{-1}$ rice yield, while $\mathrm{kg} \mathrm{Neq} \mathrm{ha}^{-1}$ year $^{-1}$ and $\mathrm{kg} \mathrm{Neq} \mathrm{kg}^{-1}$ rice yield are defined as the functional units of NF.

\subsection{Carbon Footprint Calculation}

The equations were provided by the 2019 Refinement to the 2006 IPCC Guidelines for National Greenhouse Gas Inventories [41] as follows:

$$
\begin{gathered}
\mathrm{CFI}=\frac{\mathrm{CE}_{\text {total }}-\Delta \mathrm{SOCS}_{30 \mathrm{~cm}}}{\mathrm{Y}} \\
\mathrm{CE}_{\text {total }}=\mathrm{GHG}_{\text {raw material }}+\mathrm{GHG}_{\text {transportation }}+\mathrm{GHG}_{\text {utilization }}+\mathrm{GHG}_{\mathrm{CH}_{4}}+\mathrm{GHG}_{\mathrm{N}_{2} \mathrm{O}}
\end{gathered}
$$

where CFI is the carbon footprint intensity $\left(\mathrm{kg} \mathrm{CO}_{2} \mathrm{eq} \mathrm{kg}^{-1}\right.$ rice yield), $\mathrm{CE}_{\text {total }}$ is the total GHG emissions throughout the entire process of rice production from cradle to gate $(\mathrm{kg}$ $\mathrm{CO}_{2}$ eq ha ${ }^{-1}$ year $\left.^{-1}\right), \mathrm{Y}$ is the rice yield $\left(\mathrm{kg} \mathrm{ha}^{-1}\right.$ year $\left.^{-1}\right), \mathrm{GHG}_{\text {raw material }}$ is GHG emissions during the production of raw material $\left(\mathrm{kg} \mathrm{CO}_{2} \mathrm{eq} \mathrm{ha}^{-1}\right.$ year $\left.^{-1}\right), \mathrm{GHG}_{\text {transportation }}$ is $\mathrm{GHG}$ emissions during transportation $\left(\mathrm{kg} \mathrm{CO}_{2}\right.$ eq year $\left.{ }^{-1}\right), \mathrm{GHG}_{\text {utilization }}$ is $\mathrm{GHG}$ emissions during the utilization phase of agricultural input $\left(\mathrm{kg} \mathrm{CO}_{2} \mathrm{eq} \mathrm{ha}{ }^{-1}\right.$ year $\left.{ }^{-1}\right), \mathrm{GHG}_{\mathrm{CH}_{4}}$ is the methane emissions from rice cultivation $\left(\mathrm{kg} \mathrm{CH} \mathrm{ha}^{-1}\right)$, and $\mathrm{GHG}_{\mathrm{N}_{2} \mathrm{O}}$ is the direct $\mathrm{N}_{2} \mathrm{O}$ emissions from paddy fields during rice cultivation $\left(\mathrm{kg} \mathrm{N}_{2} \mathrm{O} \mathrm{ha}{ }^{-1}\right)$. All the emission factors used were from the 2019 Refinement to the 2006 IPCC Guidelines for National Greenhouse Gas Inventories [41], The National Technical Committee on Product Carbon Footprinting (Thailand) [43], TGO [44], EPA [45], The National Technical Committee on Product Carbon Footprinting (Thailand) [46], Ecoinvent Centre [47], and Maciel et al. [48], which are provided in the Supplementary Material. 


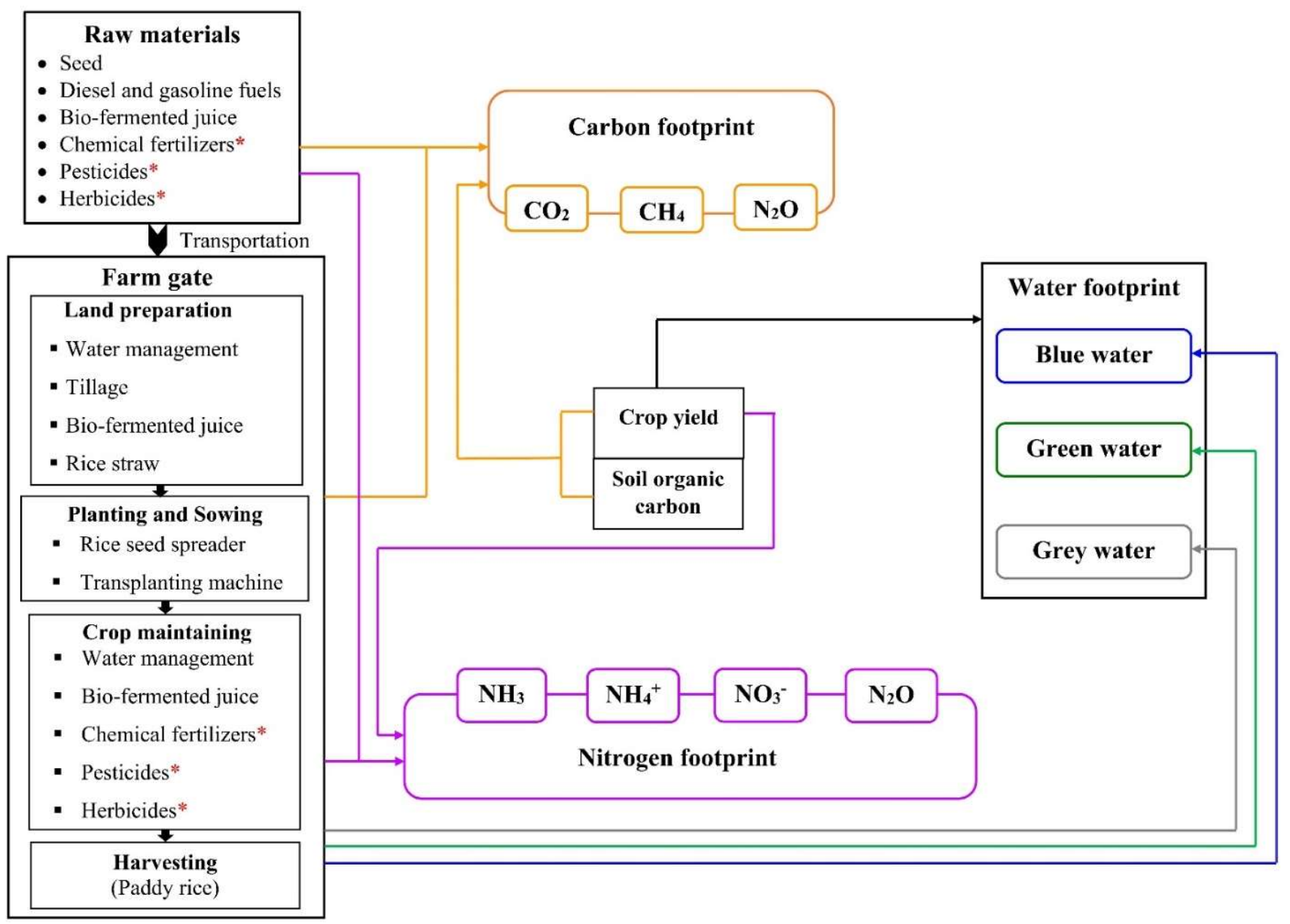

Figure 2. System boundaries for carbon, nitrogen, and water footprint assessment. * indicates that the materials were used in conventional rice farming but not applied in organic rice farming.

\subsection{Nitrogen Footprint Calculation}

In this study, NF was used to characterize the eutrophication potential that is released into the air, water and soil [49] and evaluate the $\mathrm{Nr}$ emission and losses during the entire process of rice production from cradle to gate according to ISO 14044 [50]. The formulas used in these calculations were as follows:

$$
\mathrm{NFI}=\frac{\mathrm{NE}_{\text {total }}}{\mathrm{Y}}
$$

where NFI is nitrogen footprint intensity ( $\mathrm{g} \mathrm{Neq} \mathrm{kg}^{-1}$ rice yield), $\mathrm{NE}_{\text {total }}$ is the total $\mathrm{Nr}$ emission throughout the entire process of rice production from cradle to gate ( $\mathrm{g} \mathrm{Neq} \mathrm{ha}^{-1}$ year $\left.{ }^{-1}\right)$, and $Y$ is the rice yield $\left(\mathrm{kg} \mathrm{ha}^{-1}\right.$ year $\left.^{-1}\right)$.

$$
\begin{gathered}
\mathrm{NE}_{\text {total }}=\mathrm{NE}_{\text {inputs }}+\mathrm{NV}_{\mathrm{NH}_{3}}+\mathrm{NE}_{\mathrm{N}_{2} \mathrm{O}}+\mathrm{NL}_{\mathrm{NO}_{3}^{-}}+\mathrm{NL}_{\mathrm{NH}_{4}^{+}} \\
\mathrm{NE}_{\text {inputs }}=\sum_{\mathrm{i}} \mathrm{Q}_{\text {used }_{\mathrm{i}}} \times \mathrm{Y}_{\mathrm{i}}
\end{gathered}
$$

where $\mathrm{NE}_{\text {inputs }}$ is the indirect total amount of $\mathrm{Nr}$ emissions using agricultural input (g Neq $\mathrm{ha}^{-1}$ year $\left.^{-1}\right), \mathrm{Qused}_{\mathrm{i}}$ is the amount of agricultural input type i used $\left(\mathrm{kg} \mathrm{ha}^{-1}\right.$ year $\left.{ }^{-1}\right)$, and $Y_{i}$ is the emission factor of the agricultural input type $i\left(\mathrm{~g} \mathrm{Neq} \mathrm{ha}^{-1}\right.$ year $\left.^{-1}\right)$. Due to $Y_{i}$ values being unavailable in Thailand as yet, the specific emission factors $\left(Y_{i}\right)$ from IKE eBalance v3.0 (IKE Environment Technology CO., Ltd., Chengdu, China) were used in this study. 
The $\mathrm{Nr}$ emissions and losses from the field included $\mathrm{NH}_{3}$ volatilization and $\mathrm{N}_{2} \mathrm{O}$ emission as well as $\mathrm{NO}_{3}^{-}$and $\mathrm{NH}_{4}^{+}$leaching, which were calculated by multiplying the pure amount of $\mathrm{N}$ used with the relative loss coefficient and then converting to the eutrophication potential values according to the following Equations (9)-(12).

$$
\begin{aligned}
& \mathrm{NV}_{\mathrm{NH}_{3}}=\mathrm{N} \times \varphi \times \frac{17}{14} \times 0.833 \times 1000 \\
& \mathrm{NE}_{\mathrm{N}_{2} \mathrm{O}}=\mathrm{N} \times \varnothing \times \frac{44}{28} \times 0.476 \times 1000 \\
& \mathrm{NL}_{\mathrm{NO}_{3}^{-}}=\mathrm{N} \times \varepsilon \times \frac{62}{14} \times 0.238 \times 1000 \\
& \mathrm{NL}_{\mathrm{NH}_{4}^{+}}=\mathrm{N} \times \sigma \times \frac{18}{14} \times 0.786 \times 1000
\end{aligned}
$$

where $\mathrm{NV}_{\mathrm{NH}_{3}}$ is the volatilization loss of $\mathrm{NH}_{3}$ due to $\mathrm{N}$ application ( $\mathrm{g} \mathrm{Neq} \mathrm{ha} \mathrm{year}^{-1}$ ); $\mathrm{NE}_{\mathrm{N}_{2} \mathrm{O}}$ is the cumulative amount of direct $\mathrm{N}_{2} \mathrm{O}$ emission due to fertilizer applications ( $\mathrm{g} \mathrm{Neq} \mathrm{ha}{ }^{-1}$ year ${ }^{-1}$ ); $\mathrm{NL}_{\mathrm{NO}_{3}^{-}}$is the rate of $\mathrm{NO}_{3}^{-}$leaching $\left(\mathrm{g} \mathrm{Neq} \mathrm{ha}^{-1}\right.$ year ${ }^{-1}$ ); $\mathrm{NL}_{\mathrm{NH}_{4}^{+}}$is the rate of $\mathrm{NH}_{4}^{+}$leaching ( $\mathrm{g} \mathrm{Neq} \mathrm{ha}{ }^{-1}$ year ${ }^{-1}$ ); $\varphi$ is the coefficient of $\mathrm{NH}_{3}$ volatilization loss (0.338); $\varnothing$ is the emission factor of $\mathrm{N}_{2} \mathrm{O}$ emission due to $\mathrm{N}$ application $\left(0.003 \mathrm{~kg} \mathrm{~N} \mathrm{~N}_{2} \mathrm{O}-\mathrm{N}\right.$ $\mathrm{kg}^{-1}$ of $\mathrm{N}$ for continuous flooding); $\varphi$ is the coefficient of $\mathrm{NO}_{3}^{-}$leaching $(0.305) ; \sigma$ is the coefficient of $\mathrm{NH}_{4}^{+}$leaching (0.339); 17/14,44/28,62/14, and 18/14 are the molecular weight ratios of $\mathrm{NH}_{3}$ to $\mathrm{NH}_{3}-\mathrm{N}, \mathrm{N}_{2} \mathrm{O}$ to $\mathrm{N}_{2} \mathrm{O}-\mathrm{N}, \mathrm{NO}_{3}^{-}$to $\mathrm{NO}_{3}^{-}-\mathrm{N}$, and $\mathrm{NH}_{4}^{+}$to $\mathrm{NH}_{4}^{+}-\mathrm{N}$, respectively. The values of $0.833,0.476,0.238$, and 0.786 are eutrophication potential factors of $\mathrm{NH}_{3}\left(\mathrm{~kg} \mathrm{Neq} \mathrm{kg}^{-1}\right.$ of $\left.\mathrm{NH}_{3}\right), \mathrm{N}_{2} \mathrm{O}\left(\mathrm{kg} \mathrm{Neq} \mathrm{kg}^{-1}\right.$ of $\left.\mathrm{N}_{2} \mathrm{O}\right), \mathrm{NO}_{3}^{-}\left(\mathrm{kg} \mathrm{Neq} \mathrm{kg}^{-1}\right.$ of $\left.\mathrm{NO}_{3}^{-}\right)$, and $\mathrm{NH}_{4}^{+}\left(\mathrm{kg} \mathrm{Neq} \mathrm{kg}^{-1}\right.$ of $\left.\mathrm{NH}_{4}^{+}\right)$, respectively, and 1000 is a unit conversion factor $\left(\mathrm{g} \mathrm{kg}^{-1}\right)$. In this study, the eutrophication potential factors were obtained from Guinée et al. [51] based on the CML2002 methodology. The nitrogen percentages of agricultural residues were obtained from Arunrat et al. [27].

\subsection{Water Footprint Calculation}

The total WF in the rice-growing process $\left(\mathrm{WF}_{\text {total }}, \mathrm{m}^{3} \mathrm{ton}^{-1}\right)$ is the sum of green, blue, and gray water [52-54], as in Equation (13).

$$
\mathrm{WF}_{\text {total }}=\mathrm{WF}_{\text {green }}+\mathrm{WF}_{\text {blue }}+\mathrm{WF}_{\text {grey }}
$$

The green WF and blue WF are calculated using in Equations (14) and (15), respectively.

$$
\begin{gathered}
\mathrm{WF}_{\text {green }}=\frac{\mathrm{CWU}_{\text {green }}}{\mathrm{Y}}=\frac{10 \times \sum_{\mathrm{d}=1}^{\lg p} \mathrm{ET}_{\text {green }}}{\mathrm{Y}} \\
\mathrm{WF}_{\text {blue }}=\frac{\mathrm{CWU}_{\text {blue }}}{\mathrm{Y}}=\frac{10 \times \sum_{\mathrm{d}=1}^{\operatorname{lgp}} \mathrm{ET}_{\text {blue }}}{\mathrm{Y}} \\
\mathrm{ET}_{\text {green }}=\min \left(\mathrm{ET}_{\mathrm{c}}, \mathrm{P}_{\text {eff }}\right) \\
\mathrm{ET}_{\text {blue }}=\max \left(0, \mathrm{ET}_{\mathrm{c}}-\mathrm{P}_{\text {eff }}\right)
\end{gathered}
$$

where CWU is crop water use $\left(\mathrm{m}^{3} \mathrm{ha}^{-1}\right), \mathrm{ET}_{\text {green }}$ is evapotranspiration of green water $\left(\mathrm{mm}\right.$ day $\left.^{-1}\right), \mathrm{ET}_{\text {blue }}$ is evapotranspiration of blue water $\left(\mathrm{mm} \mathrm{day}^{-1}\right), \operatorname{lgp}$ is the growing period, $\mathrm{Y}$ is rice yield (ton $\mathrm{ha}^{-1}$ year $^{-1}$ ), $\mathrm{P}_{\text {eff }}$ is the effective rainfall available, and $\mathrm{ET}_{\mathrm{C}}$ is the crop evapotranspiration. The " 0 " value is considered when $\mathrm{P}_{\text {eff }}$ exceeds crop evapotranspiration. Evapotranspiration was calculated using the CROPWAT 8.0 model.

The gray WF $\left(\mathrm{WF}_{\text {gray }}, \mathrm{m}^{3} \mathrm{ha}^{-1}\right)$ was calculated using Equation (18) [55]:

$$
\mathrm{WF}_{\text {grey }}=\frac{\alpha \times\left(\sum_{\mathrm{x}=1}^{\mathrm{n}} \mathrm{N}+\mathrm{ON}\right)}{\left(\mathrm{C}_{\max }-\mathrm{C}_{\mathrm{nal}}\right) / \mathrm{Y}}
$$


where $\alpha$ is the fraction of leaching-runoff (nitrogen $=0.1, \mathrm{IPCC}$ [56]), ON is the organic amendment rate $\left(\mathrm{kg} \mathrm{N}^{-1}\right), \mathrm{C}_{\max }$ is the maximum acceptable concentration of a load of pollutant $\left(\mathrm{NO}_{3}-\mathrm{N}<5 \mathrm{mg} \mathrm{L}^{-1}\right.$, Pollution Control Department [57]), and $\mathrm{C}_{\text {nal }}$ is the natural $\mathrm{N}$ concentration $\left(\mathrm{C}_{\text {nal }}=0 \mathrm{~kg} \mathrm{~m}^{-3}\right)$.

\subsection{Calculation of Economic Return and CF, NF, and WF Per Net Return}

The net returns from rice production of organic rice and conventional rice farms were calculated by subtracting the total costs throughout rice production processes from the total benefit of selling paddy rice each year. The CF, NF, and WF per net returns were calculated according to the equations by Yang et al. [58] and Wang et al. [59].

$$
\begin{gathered}
\mathrm{CF}_{\mathrm{E}}=\frac{\mathrm{CE}_{\text {total }}-\Delta \mathrm{SOCS}_{30 \mathrm{~cm}}}{\mathrm{R}_{\text {net }}} \\
\mathrm{NF}_{\mathrm{E}}=\frac{\mathrm{NE}_{\text {total }}}{\mathrm{R}_{\text {net }}} \\
\mathrm{WF}_{\mathrm{E}}=\frac{\mathrm{WF}_{\text {total }}}{\mathrm{R}_{\text {net }}}
\end{gathered}
$$

where $\mathrm{CF}_{\mathrm{E}}, \mathrm{NF}_{\mathrm{E}}$, and $\mathrm{WF}_{\mathrm{E}}$ are the $\mathrm{CF}, \mathrm{NF}$, and $\mathrm{WF}$ per net return in units of $\mathrm{kg} \mathrm{CO}_{2} \mathrm{eq}$ $\mathrm{THB}^{-1}$ year ${ }^{-1}$, $\mathrm{g} \mathrm{Neq} \mathrm{THB}^{-1}$ year $^{-1}$, and $\mathrm{m}^{3} \mathrm{THB}^{-1}$ year $^{-1}$, respectively, and $\mathrm{R}_{\text {net }}$ is the net economic return (THB ha ${ }^{-1}$ year $^{-1}$ ).

\subsection{Statistical Analysis}

The analyses were performed using SPSS (v. 20.0). T-tests and least significant difference (LSD) tests $(p<0.05)$ were performed to identify differences in soil properties $\left(\mathrm{CF}, \mathrm{SOC}, \mathrm{NF}, \mathrm{WF}, \mathrm{CF}_{\mathrm{E}}, \mathrm{NF}_{\mathrm{E}}\right.$, and $\mathrm{WF}_{\mathrm{E}}$ ) between $\mathrm{OF}$ and CVF.

\section{Results and Discussion}

\subsection{Input Inventory Analysis and Soil Physical and Chemical Properties}

The amounts of rice seeds needed and the gasoline used were significantly different between OF and CVF. The OF method used fewer rice seeds than the CVF one due to use of the transplanting method, while the broadcasting method was commonly used for CVF. Gasoline consumption was high in CVF compared with OF. This is because the spreader machine was used several times to spread fertilizer, herbicides, and insecticides during the crop maintenance stage. Significant differences in the diesel used and the remaining rice straw were not detected between OF and CVF. The bio-fermented juice was only applied in $\mathrm{OF}$, not in CVF, because bio-fermented juice was the main material input providing the nutrients for crop growth. Unlike in OF, the nutrients in CVF mainly came from chemical fertilizers. Clearly, the OF used much lower material inputs than the CVF (Table 1). This is consistent with the studies of Bennett and Franzell [60] and Arunrat et al. [12], who revealed that organic agriculture has not only improved the livelihoods of farmers but also minimized the external input.

The soil textures of both sites were silty clay with $8.5-16.3 \%$ sand, $43.3-47.3 \%$ silt, and $40.4-46.62 \%$ clay content. The differences in the sand, silt, and clay contents were not significant between OF and CVF. Soil bulk density (BD) ranged from 1.35 to $1.36 \mathrm{~g} \mathrm{~cm}^{-3}$ and from 1.37 to $1.40 \mathrm{~g} \mathrm{~cm}^{-3}$ for $\mathrm{OF}$ and CVF, respectively. Although the values of BD in OF and CVF were not significantly different, the BD in OF was slightly lower than that in CVF. Soil $\mathrm{pH}$ values were 5.38-5.6 and 5.03-5.54 for OF and CVF, respectively, and a significant difference was not detected. The available $\mathrm{P}$ values were not significantly different between OF and CVF, with an overall range of $11.69-18.96 \mathrm{mg} \mathrm{kg}^{-1}$. The available $\mathrm{K}$, available Ca, and available $\mathrm{Mg}$ values were found to have significant differences between OF and CVF in some years, ranging from 107.96 to $188.53,1564.0$ to 3770.4 , and 100.31 to $274.65 \mathrm{mg} \mathrm{kg}^{-1}$, respectively. The ECe values ranged from 0.25 to $0.49 \mathrm{dS} \mathrm{m}^{-1}$. Interestingly, organic matter 
(OM) was significantly different between OF and CVF. Higher OM was found in OF than in CVF: $3.16-3.20 \%$ vs. $2.75-2.82 \%$, respectively (Table 2 ).

Table 1. Agriculture input of organic rice farming and conventional rice farming during 2018-2021 (mean \pm standard deviation).

\begin{tabular}{|c|c|c|c|}
\hline \multirow{2}{*}{ Input } & \multirow{2}{*}{ Unit } & \multicolumn{2}{|c|}{ Quantity } \\
\hline & & Organic Rice Farming & Conventional Rice Farming \\
\hline Rice seeds & $\mathrm{kg} \mathrm{ha}^{-1} \mathrm{crop}^{-1}$ & $62.5 \pm 31.3 a$ & $93.8 \pm 31.3 b$ \\
\hline Gasoline & $\mathrm{L} \mathrm{ha}^{-1}$ crop $^{-1}$ & $62.5 \pm 18.8 \mathrm{a}$ & $125.0 \pm 31.3 b$ \\
\hline Diesel & $\mathrm{L} \mathrm{ha}^{-1} \mathrm{crop}^{-1}$ & $125.0 \pm 31.3 a$ & $156.3 \pm 18.8 \mathrm{a}$ \\
\hline Straw & $\mathrm{kg} \mathrm{ha}^{-1} \mathrm{crop}^{-1}$ & $3375.0 \pm 1250.0 \mathrm{a}$ & $3100.0 \pm 1250.0 \mathrm{a}$ \\
\hline Bio-fermented juice * & $\mathrm{kg} \mathrm{ha}^{-1} \mathrm{crop}^{-1}$ & $312.5 \pm 125.0$ & - \\
\hline Fertilizer $16-20-0$ & $\mathrm{~kg} \mathrm{ha}^{-1} \mathrm{crop}^{-1}$ & - & $156.3 \pm 62.5$ \\
\hline Fertilizer $46-0-0$ & $\mathrm{~kg} \mathrm{ha}^{-1} \mathrm{crop}^{-1}$ & - & $125.0 \pm 31.3$ \\
\hline Glyphosate $48 \% w / v$ SL & $\mathrm{L} \mathrm{ha}^{-1}$ crop $^{-1}$ & - & $\begin{array}{c}218.8 \pm 31.3 \\
\left(0.75 \mathrm{~L} \text { (a.i) ha }{ }^{-1}\right)\end{array}$ \\
\hline Alachlor $48 \% w / v$ EC & $\mathrm{L} \mathrm{ha}^{-1} \mathrm{crop}^{-1}$ & - & $\begin{array}{c}187.5 \pm 31.3 \\
\left(0.56 \mathrm{~L} \mathrm{(a.i)} \mathrm{ha}{ }^{-1}\right)\end{array}$ \\
\hline Acephate $75 \%$ S & $\mathrm{L} \mathrm{ha}^{-1} \mathrm{crop}^{-1}$ & - & $\begin{array}{c}406.3 \pm 62.5 \\
\left(0.41 \mathrm{~kg} \text { (a.i) ha }{ }^{-1}\right)\end{array}$ \\
\hline Chlorpyrifos $40 \%$ EC & $\mathrm{L} \mathrm{ha}^{-1} \mathrm{crop}^{-1}$ & - & $\begin{array}{c}375.0 \pm 62.5 \\
\left(0.75 \mathrm{~L} \text { (a.i) ha }{ }^{-1}\right)\end{array}$ \\
\hline
\end{tabular}

Lowercase letters ( $a$ and $b$ ) represent a significant difference in material input between organic rice farming and conventional rice farming $(p<0.05)$. a.i. $=$ active ingredient. ${ }^{*}$ Bio-fermented juice refers to the bio-extract or biological fermentation from natural resources (e.g., lemon grass, neem leaves, fruits, and vegetables) and waste (e.g., molasses and dung) to dispose of insects or weeds and enhance soil nutrients instead of chemical inputs.

Table 2. Soil physical and chemical characteristics $(0-30 \mathrm{~cm})$ of organic rice farming and conventional rice farming during 2018-2021 (mean \pm standard deviation).

\begin{tabular}{|c|c|c|c|c|c|c|c|c|}
\hline & \multicolumn{4}{|c|}{ Organic Rice Farming } & \multicolumn{4}{|c|}{ Conventional Rice Farming } \\
\hline & 2018 & 2019 & 2020 & 2021 & 2018 & 2019 & 2020 & 2021 \\
\hline $\mathrm{pH}(1: 2.5)$ & $5.61 \pm 0.31 \mathrm{a}$ & $5.38 \pm 0.56 a$ & $5.59 \pm 0.54 \mathrm{a}$ & $5.65 \pm 0.52 a$ & $5.53 \pm 0.42 a$ & $5.03 \pm 0.37 a$ & $5.48 \pm 0.61 \mathrm{a}$ & $5.54 \pm 0.57 \mathrm{a}$ \\
\hline $\mathrm{BD}\left(\mathrm{g} \mathrm{cm}^{-3}\right)$ & $1.36 \pm 0.28 \mathrm{a}$ & $1.36 \pm 0.25 a$ & $1.35 \pm 0.41 \mathrm{a}$ & $1.36 \pm 0.55 a$ & $1.40 \pm 0.32 \mathrm{a}$ & $1.37 \pm 0.35 \mathrm{a}$ & $1.40 \pm 0.46 \mathrm{a}$ & $1.38 \pm 0.43 a$ \\
\hline $\mathrm{OM}(\%)$ & $3.16 \pm 0.14 \mathrm{a}$ & $3.18 \pm 0.17 \mathrm{a}$ & $3.20 \pm 0.16 \mathrm{a}$ & $3.20 \pm 0.17 a$ & $2.75 \pm 0.15 b$ & $2.80 \pm 0.14 b$ & $2.82 \pm 0.15 b$ & $2.81 \pm 0.13 b$ \\
\hline $\mathrm{ECe}\left(\mathrm{dS} \mathrm{m}^{-1}\right)$ & $0.49 \pm 0.01 \mathrm{a}$ & $0.57 \pm 0.01 \mathrm{a}$ & $0.25 \pm 0.03 a$ & $0.37 \pm 0.02 \mathrm{a}$ & $0.36 \pm 0.02 b$ & $0.42 \pm 0.03 b$ & $0.30 \pm 0.02 \mathrm{a}$ & $0.41 \pm 0.02 \mathrm{a}$ \\
\hline $\begin{array}{l}\text { Avail. P (mg } \\
\left.\mathrm{kg}^{-1}\right)\end{array}$ & $13.01 \pm 8.32 \mathrm{a}$ & $15.06 \pm 12.10 \mathrm{a}$ & $17.57 \pm 15.32 \mathrm{a}$ & $18.6 \pm 10.51 \mathrm{a}$ & $11.69 \pm 4.32 \mathrm{a}$ & $15.34 \pm 17.54 a$ & $18.96 \pm 21.07 \mathrm{a}$ & $13.65 \pm 9.65 a$ \\
\hline $\begin{array}{c}\text { Avail. K (mg } \\
\left.\mathrm{kg}^{-1}\right)\end{array}$ & $\begin{array}{c}142.98 \pm \\
31.20 \mathrm{a}\end{array}$ & $\begin{array}{c}151.54 \pm \\
12.63 \mathrm{a}\end{array}$ & $\begin{array}{c}184.97 \pm \\
27.50 \mathrm{a}\end{array}$ & $176.5 \pm 19.54 a$ & $164.96 \pm 33.8 \mathrm{a}$ & $\begin{array}{c}188.53 \pm \\
15.07 \mathrm{a}\end{array}$ & $\begin{array}{c}107.96 \pm \\
21.18 \mathrm{~b}\end{array}$ & $157.3 \pm 25.01 a$ \\
\hline $\begin{array}{l}\text { Avail. Ca (mg } \\
\left.\mathrm{kg}^{-1}\right)\end{array}$ & $\begin{array}{c}1897.06 \pm \\
613.5 \mathrm{a}\end{array}$ & $\begin{array}{c}1965.45 \pm \\
498.3 \mathrm{a}\end{array}$ & $\begin{array}{c}2872.59 \pm \\
572.3 a\end{array}$ & $\begin{array}{c}2373.34 \pm \\
315.3 a\end{array}$ & $\begin{array}{c}3770.40 \pm \\
743.2 \mathrm{~b}\end{array}$ & $\begin{array}{c}3653.13 \pm \\
631.4 \mathrm{~b}\end{array}$ & $\begin{array}{c}1564.00 \pm \\
287.56 \mathrm{~b}\end{array}$ & $\begin{array}{c}2567.40 \pm \\
267.4 \mathrm{a}\end{array}$ \\
\hline $\begin{array}{l}\text { Avail. } \mathrm{Mg}(\mathrm{mg} \\
\left.\mathrm{kg}^{-1}\right)\end{array}$ & $138.14 \pm 54.3 a$ & $157.89 \pm 48.6 a$ & $178.93 \pm 74.2 \mathrm{a}$ & $168.9 \pm 39.6 \mathrm{a}$ & $216.38 \pm 61.5 b$ & $274.65 \pm 71.3 b$ & $100.31 \pm 49.5 b$ & $218.5 \pm 55.2 \mathrm{a}$ \\
\hline Sand $(\%)$ & $9.8 \mathrm{a} \pm 3.75 \mathrm{a}$ & $10.1 \pm 3.60 \mathrm{a}$ & $8.5 \pm 3.11 \mathrm{a}$ & $9.61 \pm 4.21 \mathrm{a}$ & $12.3 \pm 4.07 \mathrm{a}$ & $15.3 \pm 4.31 \mathrm{a}$ & $14.3 \pm 4.25 \mathrm{a}$ & $16.3 \pm 6.72 \mathrm{a}$ \\
\hline Silt (\%) & $44.9 \pm 10.43 a$ & $47.3 \pm 9.11 \mathrm{a}$ & $46.2 \pm 8.75 \mathrm{a}$ & $43.77 \pm 7.85 \mathrm{a}$ & $44.6 \pm 8.54 \mathrm{a}$ & $43.9 \pm 9.23 a$ & $44.2 \pm 8.06 \mathrm{a}$ & $43.3 \pm 7.91 \mathrm{a}$ \\
\hline Clay (\%) & $45.3 \pm 6.21 \mathrm{a}$ & $42.6 \pm 4.98 \mathrm{a}$ & $45.3 \pm 7.61 \mathrm{a}$ & $46.62 \pm 6.99 \mathrm{a}$ & $43.1 \pm 5.55 a$ & $40.8 \pm 5.08 \mathrm{a}$ & $41.5 \pm 9.43 a$ & $40.4 \pm 7.03 a$ \\
\hline Soil Texture & Silty Clay & Silty Clay & Silty Clay & Silty Clay & Silty Clay & Silty Clay & Silty Clay & Silty Clay \\
\hline
\end{tabular}

Lowercase letters ( $a$ and $b$ ) represent significant differences in soil properties between organic rice farming and conventional rice farming of each year $(p<0.05)$. BD = bulk density; $\mathrm{OM}=$ organic matter; ECe = electrical conductivity; Avail. $\mathrm{P}=$ available phosphorous; Avail. $\mathrm{K}=$ available potassium; Avail. Ca = available calcium; Avail. $\mathrm{Mg}$ = available magnesium. 
Although there was an insignificant difference in $\mathrm{pH}$ between $\mathrm{OF}$ and $\mathrm{CVF}$, the $\mathrm{pH}$ in OF was slightly higher than that in CVF (Table 2). This is because using chemical fertilizers decreased the soil $\mathrm{pH}$. This is consistent with the study of Sun et al. [61], who mentioned that the long-term use of chemical fertilizers could significantly reduce the soil $\mathrm{pH}$, resulting in decreased bacterial diversity in the soil. Moreover, the transformation of nitrogen fertilizer into different forms influences soil acidification, which depends on the type of nitrogen, the soil buffering capacity, and the net balance of proton-generating and consuming processes [62]. On the other hand, applying organic fertilizer or organic materials can alleviate these negative effects in the long term [63]. This is also supported by the studies of Rukshana et al. [64] and Sun et al. [61], who reported that the alkalinity of livestock manures could enhance the soil $\mathrm{pH}$ and prevent negative effects on soil bacteria. Similar to the soil $\mathrm{pH}$, the BD in OF was a little lower than that in CVF (Table 2). This can be explained by the practice of organic rice farming, where retaining and incorporating rice residue in the soil decreases $\mathrm{BD}$. In this study, the rice residue in OF has been retained in the rice field for more than 10 years, while the rice residue in CVF was removed or burnt in some years. Gathala et al. [65] reported that crop residue retention can improve soil quality and decrease bulk density due to increasing OM, resulting in soil compaction reduction and crop root growth enhancement $[66,67]$. It was found in the present study that the OM in OF was higher than that in CVF (Table 2). OM is an important factor in providing the necessary nutrient elements for plants; it enhances the activity of soil microorganisms, loosens the soil structure, decreases BD, and increases the cation exchange capacity [68]

\subsection{Soil Organic Carbon Stock of OF and CVF}

The SOC stocks were significantly higher in OF than in CVF from years 2018 to 2021. The $\triangle$ SOCS stocks increased by $147.3 \mathrm{~kg} \mathrm{C} \mathrm{ha}^{-1}$ year $^{-1}\left(539.9 \mathrm{~kg} \mathrm{CO}_{2}\right.$ eq ha ${ }^{-1}$ year $^{-1}$ ) in OF, while the annual SOC stock value in CVF increased by $86.3 \mathrm{~kg} \mathrm{C} \mathrm{ha-1}$ year $^{-1}$ (316.3 $\mathrm{kg} \mathrm{CO}_{2}$ eq ha ${ }^{-1}$ year $^{-1}$ ), as shown in Table 3. Thus, the increase in SOC is an effective measure to mitigate $\mathrm{CO}_{2}$ emissions, contributing to climate change mitigation through carbon fixation into the soil. Hiederer and Köchy [69], estimated the global SOC stocks at a $1 \mathrm{~m}$ depth, which contained $1206 \mathrm{Pg} \mathrm{C}$ (574 and $632 \mathrm{Pg} \mathrm{C}$ for the earth's topsoil [0-30 cm] and subsoil [30-100 cm], respectively). It was greater than the atmospheric carbon stock (800 Pg C) [70]. This indicated that a small increase in SOC stock can play a crucial role in GHG reduction in the atmosphere [71]. Most of the agricultural soil carbon pool is an active carbon pool, which is important for crop productivity and the soil carbon cycle [23]. As shown in Table 3, both types of rice cultivation have the potential to sequester soil carbon in paddy soils. Indeed, Pan et al. [24] and Pan et al. [72] proved that paddy soils have higher potential than croplands. The SOC stock was higher in OF than in CVF (Table 3). This is because adding the bio-fermented juice and carbon inputs from the turnover of roots, return of rice residue, root exudates, and rhizodeposits helps to increase SOC sequestration [73-75].

Table 3. SOC stock and SOC sequestration rate from 2018 to 2021.

\begin{tabular}{|c|c|c|c|c|}
\hline Practice & $\begin{array}{l}\text { SOC } 2018 \\
\left(\operatorname{kg~C~ha~}^{-1}\right)\end{array}$ & $\begin{array}{c}\text { SOC } 2021 \\
\left(\mathrm{~kg} \mathrm{C} \mathrm{ha-1)}^{-1}\right)\end{array}$ & $\begin{array}{c}\Delta S O C S \\
\left(\mathrm{~kg} \mathrm{C} \mathrm{ha}^{-1} \text { year }^{-1}\right)\end{array}$ & $\begin{array}{c}\Delta S O C S \\
\left(\mathrm{~kg} \mathrm{CO}_{2} \text { eq ha }\right. \\
\left.\text { he } \text { year }^{-1}\right)\end{array}$ \\
\hline Organic rice farming & $74,784.2 \mathrm{a}$ & $75,226.0 \mathrm{a}$ & 147.3 & 539.9 \\
\hline Conventional rice farming & $66,995.4 a$ & $67,254.2 a$ & 86.3 & 316.3 \\
\hline
\end{tabular}

It should be noted that changing land management practices from CVF to OF can increase soil carbon sinks, but the soil carbon level may decrease at the beginning if there is an intensive disturbance (e.g., intensive tillage, elimination of all rice residues, and removal of topsoil). Moreover, the rate of carbon removal from the atmosphere into the soil decreases with time because a new equilibrium is reached [76]. Paustian [77] and IPCC [78] stated that IPCC used a figure of 20 years for soil carbon to reach a new equilibrium in the IPCC 
good practice guidelines for GHG inventories. This implies that nearly 20-30 years after a land use change, the capacity of the soil to stock further quantities of carbon is near zero and may begin to decline if the soils are significantly disturbed. Therefore, implementation of soil carbon sequestration measures should be considered within a broader framework of sustainable development and possible policy implications [76,79].

\subsection{Greenhouse Gas Emissions and Carbon Footprint of OF and CVF}

The rice yield in CVF was nearly two times higher than that in OF (Table 4). This was due to the use of chemical fertilizers, which enhances crop growth and maintains the crop yield better than the use of bio-fermented juice. Moreover, herbicide and insecticide application in CVF is more efficient at protecting and eliminating weeds and diseases than the application of bio-fermented juice in $\mathrm{OF}$, leading to less reduction in the rice yield in CVF. With the higher material input in CVF than in OF, the total GHG of CVF was significantly higher than that in $\mathrm{OF}$, with values of 5238.0 and $3829.0 \mathrm{~kg} \mathrm{CO}_{2} \mathrm{eq} \mathrm{ha}{ }^{-1}$ year $^{-1}$, respectively. In the raw material production stage, significant differences in GHG emissions between OF and CVF were found for rice seeds, gasoline, and diesel production. Chemical fertilizer production of CVF generated the highest GHG emissions in this stage, with a value of $884.2 \mathrm{~kg} \mathrm{CO}_{2}$ eq ha $^{-1}$ year $^{-1}$. Throughout the life cycle of rice production, rice planting until the harvesting period is the largest stage of GHG emissions, especially $\mathrm{CH}_{4}$ emission. No significant difference was found for $\mathrm{CH}_{4}$ emissions between OF $\left(2932.2 \mathrm{~kg} \mathrm{CO}_{2} \mathrm{eq} \mathrm{ha}^{-1}\right.$ year $^{-1}$ ) and CVF (2876.8 $\mathrm{kg} \mathrm{CO}_{2} \mathrm{eq} \mathrm{ha}^{-1}$ year $^{-1}$ ). GHG emissions from gasoline, diesel, and direct $\mathrm{N}_{2} \mathrm{O}$ in $\mathrm{CVF}$ were significantly higher than those in $\mathrm{OF}$, especially direct $\mathrm{N}_{2} \mathrm{O}$. This is mainly due to $\mathrm{N}_{2} \mathrm{O}$ emissions emitted from the chemical fertilizers used. Notably, net GHG emissions in OF (3289.1 kg CO $2 \mathrm{eq} \mathrm{ha}^{-1}$ year $^{-1}$ ) were significantly lower than those in CVF (4921.7 kg CO 2 eq ha ${ }^{-1}$ year $^{-1}$ ), indicating that organic farms can mitigate the net GHG emissions with soil carbon sequestration; see Table 4.

Table 4. GHG emissions of organic rice farming and conventional rice farming during 2018-2021 (mean \pm standard deviation).

\begin{tabular}{|c|c|c|c|}
\hline \multicolumn{2}{|c|}{ Life Cycle Stage } & \multirow{2}{*}{$\begin{array}{c}\text { Organic Rice Farming } \\
15.6 \pm 0.3 \mathrm{a}\end{array}$} & \multirow{2}{*}{$\begin{array}{c}\text { Conventional Rice Farming } \\
23.5 \pm 0.5 b\end{array}$} \\
\hline \multirow{7}{*}{$\begin{array}{l}\text { Raw material production }(\mathrm{kg} \mathrm{CO} \text { eq } \\
\left.\qquad \mathrm{ha}^{-1} \text { year }^{-1}\right)\end{array}$} & Seeds & & \\
\hline & Gasoline & $21.3 \pm 0.7 \mathrm{a}$ & $42.6 \pm 0.7 \mathrm{~b}$ \\
\hline & Diesel & $48.3 \pm 1.2 \mathrm{a}$ & $60.4 \pm 1.9 b$ \\
\hline & Bio-fermented juice & $79.8 \pm 5.1$ & 0 \\
\hline & Chemical fertilizers & 0 & $884.2 \pm 221.1$ \\
\hline & Herbicides & 0 & $72.6 \pm 9.5$ \\
\hline & Pesticides & 0 & $48.8 \pm 9.8$ \\
\hline \multirow{7}{*}{ Field emission $\left(\mathrm{kg} \mathrm{CO}_{2}\right.$ eq ha ${ }^{-1}$ year $\left.^{-1}\right)$} & Gasoline & $144.9 \pm 4.6 \mathrm{a}$ & $289.9 \pm 4.6 b$ \\
\hline & Diesel & $343.1 \pm 8.2 \mathrm{a}$ & $428.8 \pm 13.7 b$ \\
\hline & Herbicides & 0 & $100.6 \pm 15.1$ \\
\hline & Pesticides & 0 & $31.9 \pm 6.4$ \\
\hline & $\mathrm{CH}_{4}$ & $2932.2 \pm 1570.0 \mathrm{a}$ & $2876.8 \pm 1684.5 a$ \\
\hline & direct $\mathrm{N}_{2} \mathrm{O}$ & $122.5 \pm 17.9 a$ & $256.8 \pm 43.4 b$ \\
\hline & Harvesting & $121.3 \pm 15.2 \mathrm{a}$ & $121.3 \pm 15.2 \mathrm{a}$ \\
\hline \multicolumn{2}{|c|}{ Total GHG (kg CO eq ha $^{-1}$ year $\left.^{-1}\right)$} & $3829.0 \pm 1623.1 \mathrm{a}$ & $5238.0 \pm 2026.1 b$ \\
\hline \multicolumn{2}{|c|}{ Net GHG emissions $\left(\mathrm{kg} \mathrm{CO}_{2} \mathrm{eq} \mathrm{ha}^{-1}\right.$ year $\left.^{-1}\right)$} & $3289.1 \pm 1085.2 \mathrm{a}$ & $4921.7 \pm 1254.8 b$ \\
\hline \multicolumn{2}{|c|}{ Yield (kg ha ${ }^{-1}$ year $\left.^{-1}\right)$} & $2812.5 \pm 625.0 \mathrm{a}$ & $5312.5 \pm 750.0 b$ \\
\hline \multicolumn{2}{|c|}{$\mathrm{CF}$ intensity $\left(\mathrm{kg} \mathrm{CO}_{2} \mathrm{eq} \mathrm{kg}^{-1}\right.$ rice yield) } & $1.17 \pm 0.78 \mathrm{a}$ & $0.93 \pm 0.64 b$ \\
\hline
\end{tabular}


The higher the agricultural inputs consumed, the higher the GHG emissions [80-82], which was the case in our study where the total GHG emissions were significantly higher in CVF than in OF (Table 4). The chemical fertilizers and fossil fuels in both raw material production and utilization phases were detected as the second and third hotspots of GHG emissions in CVF (Table 4). Obviously, the CVF used a high amount of chemical fertilizers, whereas they were not used in OF. This is consistent with the study of Zhang et al. [83] and Arunrat et al. [6], who reported that nitrogen fertilizer production dominated GHG emissions. Moreover, there was a higher frequency of use of a diesel water pump in CVF for draining the water from the natural ditch into the paddy field, while in OF the personal water pond was drained by gravity, or the diesel water pump used only a few times per year. The first hotspot of GHG emission was $\mathrm{CH}_{4}$ emission in both OF and CVF (Table 4). Dubey [84], Yu et al. [85], and Yan et al. [86] explained that $\mathrm{CH}_{4}$ was produced by methanogenic bacteria under obligate anaerobic conditions with a low soil Eh. Alam et al. [87] and Bacenetti et al. [88] estimated that $\mathrm{CH}_{4}$ was the main hotspot and contributed approximately $60 \%$ of total GHG emissions of rice production. In our study, the farmers of both farms preferred to grow rice under continuously flooded conditions because this practice prevents weed growth and water stress conditions in paddy fields. Higher $\mathrm{CH}_{4}$ emission was found in $\mathrm{OF}$ than in $\mathrm{CVF}$, but lower $\mathrm{N}_{2} \mathrm{O}$ emissions were seen along with lower GHG emissions from herbicide and pesticide usage (Table 4). Kanter and Searchinger [89] analyzed metadata and reported that enhanced-efficiency fertilizers, using nitrification inhibitors and polymer coatings, could reduce $\mathrm{N}_{2} \mathrm{O}$ emissions and nitrogen leaching by approximately 25-60\%. Meanwhile, Fan et al. [90], suggested that reducing pesticide application by adopting the use of biological control could reduce GHG emissions.

The intensities of CF in OF and CVF were significantly different, with values of 1.17 and $0.93 \mathrm{~kg} \mathrm{CO}_{2} \mathrm{eq} \mathrm{kg}^{-1}$ rice yield, respectively. There was a remarkably higher CF intensity in OF than in CVF due to the lower yield (Table 4). Compared with another study in Thailand, Arunrat et al. [12] used a similar calculation method to that in the present study and found that the CF intensities of organic rice and conventional rice farming in the Phichit province, lower Northern Thailand, were -0.13 and $0.82 \mathrm{~kg} \mathrm{CO}_{2} \mathrm{eq} \mathrm{kg}{ }^{-1}$ rice yield, respectively. Arunrat and Pumijumnong [91] reported that the CF values of rice production in the Roi-Et province, Northeast Thailand, ranged from 0.31 to $1.68 \mathrm{~kg} \mathrm{CO}_{2} \mathrm{eq} \mathrm{kg}^{-1}$ rice yield. Champrasert et al. [92] estimated the CF of upland rice production in the Chiang Mai province, Northern Thailand, by including aboveground carbon and SOC stock. They found 0.13 and $0.19 \mathrm{~kg} \mathrm{CO}_{2} \mathrm{eq} \mathrm{kg}^{-1}$ rice yield (unmilled rice) for the Karen and Lawa tribes, respectively. The differences in CF values compared to the present study were due to the different amounts of agricultural inputs and SOC stocks that varied in different soil textures and climate conditions.

In addition, Thanawong et al. [93] found a rice yield of $2.97 \mathrm{~kg} \mathrm{CO}_{2} \mathrm{eq} \mathrm{kg}^{-1}$ for the CF of conventional rice production of rainfed areas in the rainy season, Northeast Thailand, while irrigated areas in the dry and rainy seasons had 4.87 and $5.55 \mathrm{~kg} \mathrm{CO}_{2} \mathrm{eq} \mathrm{kg}^{-1}$ rice yield, respectively. Arunrat et al. [6] revealed that the CF of conventional rice production in the Phichit province, lower Northern Thailand, varied from 1.81 to 2.87 and 1.72 to $2.70 \mathrm{~kg}$ $\mathrm{CO}_{2} \mathrm{eq} \mathrm{kg}^{-1}$ rice yield for irrigated and rainfed areas, respectively. Yodkhum et al. [94] estimated that the $\mathrm{CF}$ of organic rice production in the Chiang Mai province, Northern Thailand, was $0.58 \mathrm{~kg} \mathrm{CO}_{2} \mathrm{eq} \mathrm{kg}^{-1}$ rice yield. Yodkhum et al. [95] calculated the CF of conventional rice farming in the Maerim District, Chiang Mai province, Northern Thailand, and found $0.64 \mathrm{~kg} \mathrm{CO}_{2} \mathrm{eq} \mathrm{kg}^{-1}$ rice yield. Mungkung et al. [96] found that the CF of Hom Mali organic rice production in the Surin province, Northeast Thailand was $2.88 \mathrm{~kg} \mathrm{CO}_{2} \mathrm{eq}$ $\mathrm{kg}^{-1}$ rice yield. When comparing the present study with the above studies, the different $\mathrm{CF}$ values are mainly due to the different amounts of agricultural inputs, methods, and parameters for the life cycle assessment (LCA) calculation, and none of the above studies considered SOC stocks.

Although reduction of the $\mathrm{CF}$ at production scale can be succeeded by an increase in crop yields, several studies [34,97-100] have stated that SOC sequestration is a key factor 
influencing CF and GHG emissions, as well as substantially increasing crop yields [101] and improving soil properties [102]. This is because any farming practices for crop production directly affect soil carbon increases or losses that have positive or negative impacts on environmental quality. Therefore, our study also suggested that the SOC sequestration should be taken into account for CF calculation in the LCA study, especially in crop production, which is critically important to estimate as to the net life cycle GHG emission.

\subsection{Reactive Nitrogen Emissions and Nitrogen Footprints of OF and CVF}

The total Nr emission in CVF was significantly higher than that in OF, with values of $63,422.5$ and $950.9 \mathrm{~kg} \mathrm{Neq} \mathrm{ha}^{-1}$ year $^{-1}$, respectively. Most of the NF was attributed to $\mathrm{NH}_{3}$ volatilization as well as $\mathrm{NO}_{3}{ }^{-}$and $\mathrm{NH}_{4}{ }^{+}$leaching. These values were roughly 67 times higher in CVF than in OF. The Nr emissions in OF related to agricultural input and in the form of $\mathrm{N}_{2} \mathrm{O}$ were very little $\left(0.014\right.$ and $2.11 \mathrm{~kg} \mathrm{Neq} \mathrm{ha}^{-1}$ year $^{-1}$, respectively) compared with CVF (173.3 and $140.8 \mathrm{~kg} \mathrm{Neq} \mathrm{ha}{ }^{-1}$ year $^{-1}$, respectively; Table 5).

Table 5. Nitrogen footprint of organic rice farming and conventional rice farming during 2018-2021 (mean \pm standard deviation).

\begin{tabular}{|c|c|c|c|c|c|c|c|}
\hline \multirow[b]{2}{*}{ Practice } & \multicolumn{5}{|c|}{ Nitrogen Footprint (kg Neq ha ${ }^{-1}$ Year $^{-1}$ ) } & \multirow{2}{*}{$\begin{array}{c}\text { Total } \\
\left(\mathrm{kg} \mathrm{Neq} \mathrm{ha}^{-1}\right. \\
\left.\text { Year }^{-1}\right)\end{array}$} & \multirow{2}{*}{$\begin{array}{l}\text { NF Intensity } \\
\text { (kg Neq kg }^{-1} \\
\text { Rice Yield) }\end{array}$} \\
\hline & $\begin{array}{l}\text { Agricultural } \\
\text { Inputs }\end{array}$ & $\mathrm{N}_{2} \mathrm{O}$ & $\mathrm{NH}_{3}$ & $\mathrm{NO}_{3}^{-}$ & $\mathrm{NH}_{4}^{+}$ & & \\
\hline $\begin{array}{l}\text { Organic rice } \\
\text { farming }\end{array}$ & $0.014 \pm 0.010 \mathrm{a}$ & $2.11 \pm 1.1 \mathrm{a}$ & $322.4 \pm 167.8 \mathrm{a}$ & $303.2 \pm 104.1 \mathrm{a}$ & $323.1 \pm 112.0 \mathrm{a}$ & $950.9 \pm 378.8 \mathrm{a}$ & $0.34 \pm 0.21 \mathrm{a}$ \\
\hline $\begin{array}{l}\text { Conventional } \\
\text { rice farming }\end{array}$ & $173.3 \pm 25.2 b$ & $140.8 \pm 45.2 b$ & $21,448.5 \pm 2105.6 b$ & $20,167.6 \pm 1780.6 b$ & $21,492.2 \pm 1967.5 b$ & $63,422.5 \pm 7866.3 b$ & $11.94 \pm 5.3 b$ \\
\hline
\end{tabular}

Lowercase letters ( $a$ and $b$ ) represent significant differences in values between organic rice farming and conventional rice farming $(p<0.05)$.

As shown in Table 5, the intensities of NF in OF and CVF were significantly different, with values of 0.34 and $11.94 \mathrm{~kg} \mathrm{Neq} \mathrm{kg}^{-1}$ rice yield, respectively. Due to the absence of studies on the NF of rice production in Thailand, comparisons with findings in other countries were discussed. Xue and Landis [103], used the LCA method to estimate the NF of cereal production in the Gulf of Mexico and found that the NF was around $2.65 \mathrm{~g}$ Neq $\mathrm{kg}^{-1}$ yield. Pierer et al. [104] applied an input-output analysis, indicating that the NF of grain production in Austria was around $21.9 \mathrm{~g} \mathrm{Neq} \mathrm{kg}^{-1}$ yield. Xue et al. [105], indicated that the NFs of the early, late, and double rice in Southern China were 10.47, 10.89, and $10.68 \mathrm{~g} \mathrm{Neq} \mathrm{kg}^{-1}$ yield, respectively. Chen et al. [22], using the LCA method, indicated that the NFs were 11.6, 13.4, and $15.4 \mathrm{~g} \mathrm{Neq} \mathrm{kg}^{-1}$ yield for double rice, rice-wheat, and wheatmaize, respectively. The NF of the present study (Table 5) was very low compared with that of the above studies. This is due to lower nitrogen material inputs, especially nitrogen fertilizers, than were used in the above studies. Chen et al. [106], mentioned that nitrogen application leads to $\mathrm{NH}_{3}$ volatilization, $\mathrm{N}_{2} \mathrm{O}$ emissions, and increased nitrogen leaching.

\subsection{Water Footprint of $O F$ and CVF}

The total WF was higher in CVF $\left(1470.1 \mathrm{~m}^{3}\right.$ ton $\left.^{-1}\right)$ than in OF $\left(1216.3 \mathrm{~m}^{3}\right.$ ton $\left.^{-1}\right)$, but a significant difference was not found. The green and blue WFs in OF were 1117.1 and $82.0 \mathrm{~m}^{3}$ ton $^{-1}$, respectively, while in CVF, they were 991.4 and $43.4 \mathrm{~m}^{3}$ ton $^{-1}$, respectively. The difference in green WF between OF and CVF was due to the differences in planting dates and the growing periods of rice varieties until harvest. Notably, the gray water was significantly higher in CVF than in OF, with values of 435.3 and $17.2 \mathrm{~m}^{3}$ ton $^{-1}$, respectively (Figure 3). This is mainly due to the use of chemical fertilizers, herbicides, and pesticides in CVF. The proportions of green, blue, and gray WFs in OF were 91.8, 6.7, and 1.4\%, respectively, while accounting for 67.4, 3.0, and 29.6\% for CVF, respectively (Figure 3). Globally, the averages of green and blue WFs of paddy rice were 618 and $720 \mathrm{~m}^{3}$ ton $^{-1}$, respectively [107]. Johannes et al. [108] reported that the total WF of the organic rice commodity in Indonesia was $1145 \mathrm{~m}^{3}$ ton $^{-1}$, consisting of $88.86 \%$ green WF, $9.00 \%$ blue $\mathrm{WF}$, and $2.14 \%$ gray WF. Their results revealed that organic rice production could save 
around $52.8 \%$ of WF compared to conventional rice production. Although a significant difference in total WF between OF and CVF in our study was not found, it showed that OF contained around 17.3\% of total WF lower than CVF (Table 4) due to the lower gray WF resulting from not applying any chemical fertilizers, which is also supported by the studies of Galloway and Cowling [109] and Benbi [110]. Thirkell et al. [111], stated that replacing chemical fertilizer with mycorrhizal fungi is an effective option for reducing gray WF. Therefore, it is of great value to switch from conventional rice production to organic rice production to reduce gray $\mathrm{WF}$, which results in reductions in total nitrogen surplus accumulation in soils and releases to rivers and groundwater.

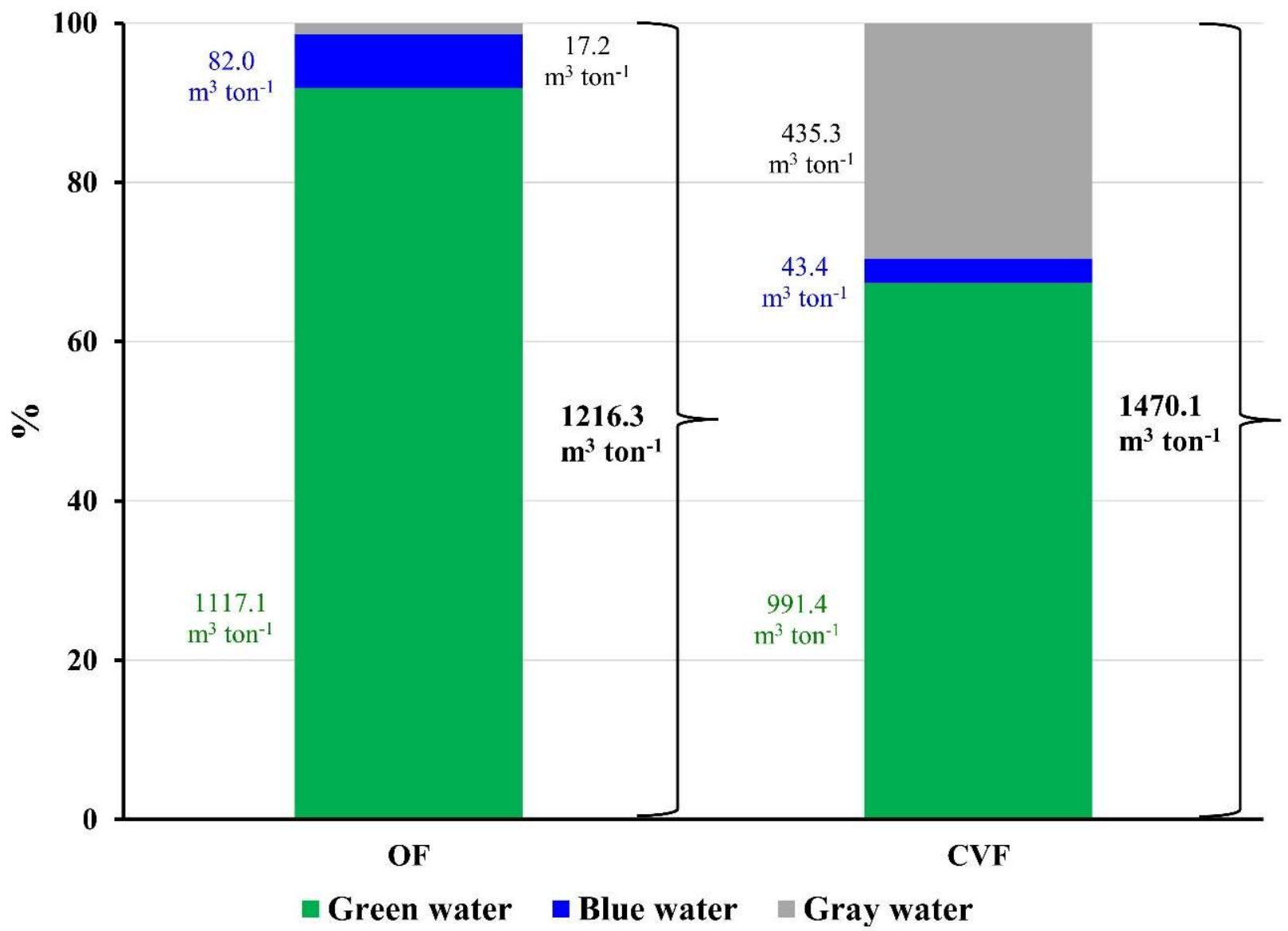

Figure 3. Comparison of water footprint.

\subsection{Economic Return and CF, NF, and WF per Net Return}

OF can give higher net economic returns than CVF, gaining around 34,580 and $18,231 \mathrm{THB} \mathrm{ha}^{-1}$ year $^{-1}$, respectively, which is due to lower production costs and higher rice prices. Concerning environmental indicators per net return, the $C F, N F$, and WF per net return values in $\mathrm{OF}$ were $0.09 \mathrm{~kg} \mathrm{CO}_{2} \mathrm{eq} \mathrm{THB}^{-1}$ year $^{-1}, 0.03 \mathrm{~kg} \mathrm{Neq} \mathrm{THB}^{-1}$ year $^{-1}$, and $98.9 \mathrm{~m}^{3} \mathrm{THB}^{-1}$ year ${ }^{-1}$, respectively. Meanwhile, the values of $0.27 \mathrm{~kg} \mathrm{CO}_{2} \mathrm{eq} \mathrm{THB}^{-1}$ year $^{-1}$, $3.48 \mathrm{~kg} \mathrm{Neq} \mathrm{THB}^{-1}$ year ${ }^{-1}$, and $428.4 \mathrm{~m}^{3} \mathrm{THB}^{-1}$ year $^{-1}$ were generated in CVF for the $\mathrm{CF}, \mathrm{NF}$, and WF per net returns, respectively (Table 6). It is clear that OF generated much lower values than CVF, indicating that rice cultivation as organic rice has a lower impact on the environment when gaining a unit of net return. By considering the four key sustainability perspectives (productivity, environmental impact, economic viability, and social wellbeing) [10], relying on local resources or those inside the farm can greatly reduce the production costs, increase the farmer's income, and reduce the impacts on the environment. To archive these sustainability perspectives, OF practices can be an effective choice. Moreover, the farmers, as water users, should be concerned about water-saving awareness regarding the water crisis in the future. 
Table 6. Economic return and CF, NF, and WF per net return of organic rice farming and conventional rice farming (mean \pm standard deviation).

\begin{tabular}{|c|c|c|c|c|c|c|}
\hline Practice & $\begin{array}{c}\text { Total Cost } \\
\text { (THB ha }{ }^{-1} \text { Year }^{-1} \text { ) }\end{array}$ & $\begin{array}{c}\text { Total Revenue } \\
\text { (THB ha }^{-1} \text { Year }^{-1} \text { ) }\end{array}$ & $\begin{array}{c}\text { Net Economic } \\
\text { Return } \\
\left(\text { THB ha }{ }^{-1} \text { Year }^{-1}\right)\end{array}$ & $\begin{array}{c}\text { CF Per Net Return } \\
\left(\mathrm{kg} \mathrm{CO}_{2} \text { eq THB }^{-1}\right. \\
\left.\text { Year }^{-1}\right)\end{array}$ & $\begin{array}{c}\text { NF Per Net Return } \\
\left(\text { kg Neq THB }^{-1}\right. \\
\left.\text { Year }^{-1}\right)\end{array}$ & $\begin{array}{l}\text { WF Per Net Return } \\
\left(\mathrm{m}^{3} \text { THB }^{-1} \text { Year }^{-1}\right)\end{array}$ \\
\hline $\begin{array}{l}\text { Organic rice } \\
\text { farming }\end{array}$ & $10,420.0 \pm 8125.0 \mathrm{a}$ & $45,000.0 \pm 9375.0 \mathrm{a}$ & $34,580 \pm 9375.0 \mathrm{a}$ & $0.09 \pm 0.03 a$ & $0.03 \pm 0.02 \mathrm{a}$ & $98.9 \pm 41.34 \mathrm{a}$ \\
\hline $\begin{array}{l}\text { Conventional rice } \\
\text { farming }\end{array}$ & $21,612.8 \pm 13,625.0 b$ & $39,843.8 \pm 12,500.0 \mathrm{~b}$ & $18,231 \pm 12,500.0 \mathrm{~b}$ & $0.27 \pm 0.08 b$ & $3.48 \pm 1.88 b$ & $428.4 \pm 253.7 b$ \\
\hline
\end{tabular}

Lowercase letters $(\mathrm{a}$ and $\mathrm{b})$ represent significant differences in values between organic rice farming and conventional rice farming $(p<0.05)$. THB is the official currency of Thailand (Thai Baht). Organic rice prices were 15-18 THB kg-1. Conventional rice prices were 7.0-7.5 THB kg-1 (Data were obtained from the farm owners during 2018-2021)

\subsection{Limitations and Recommendations for Further Study}

Although 4 years of rice cultivation were investigated in this study, the number of field studies is still limited due to the difficulty of exploring organic and conventional rice farms with similar environmental conditions. It allowed these two specific fields to be compared, whereas a generalized assessment of organic versus conventional rice production in Thailand needs a larger number of field studies and long-term monitoring to draw a wider conclusion. The challenges for future studies are (1) exploring field studies with a fair comparison, especially for soil texture; (2) reducing the uncertainty arising from agriculture inputs; (3) accessing the emission factors for the specific type of inputs to estimate the footprints.

\section{Conclusions}

Over the 4 years of the study (2018-2021), the SOC stocks in OF were significantly higher than those in CVF. The net GHG emissions in OF (3289.1 $\mathrm{kg} \mathrm{CO}_{2} \mathrm{eq} \mathrm{ha}^{-1}$ year $\left.{ }^{-1}\right)$ were significantly lower than in CVF $\left(4921.7 \mathrm{~kg} \mathrm{CO}_{2} \mathrm{eq} \mathrm{ha}^{-1}\right.$ year $\left.^{-1}\right)$. There was a remarkably higher CF intensity in OF $\left(1.17 \mathrm{~kg} \mathrm{CO}_{2} \mathrm{eq} \mathrm{kg}^{-1}\right.$ rice yield $)$ than in CVF $\left(0.93 \mathrm{~kg} \mathrm{CO}_{2} \mathrm{eq} \mathrm{kg}^{-1}\right.$ rice yield). The intensities of NF in OF and CVF were significantly different, with values of 0.34 and $11.94 \mathrm{~kg} \mathrm{Neq} \mathrm{kg}^{-1}$ rice yield, respectively. The total WF of CVF $\left(1470.1 \mathrm{~m}^{3}\right.$ ton $\left.^{-1}\right)$ was higher than that in OF $\left(1216.3 \mathrm{~m}^{3}\right.$ ton $\left.^{-1}\right)$. It is notable that the gray water in CVF was significantly higher than that in OF, with values of 435.3 and $17.2 \mathrm{~m}^{3}$ ton $^{-1}$, respectively, which was mainly due to the use of chemical fertilizers, herbicides, and pesticides in CVF. Although the rice yield in OF was nearly two times lower than that in CVF, the economic return in OF was higher than that in CVF, gaining around 34,580 and 18,231 THB ha ${ }^{-1}$ year $^{-1}$, respectively, which is due to lower production costs and higher rice prices. The $\mathrm{CF}, \mathrm{NF}$, and WF per net return values in OF were $0.09 \mathrm{~kg} \mathrm{CO}_{2} \mathrm{eq} \mathrm{THB}^{-1}$ year $^{-1}, 0.03 \mathrm{~kg}$ $\mathrm{Neq} \mathrm{THB}^{-1}$ year ${ }^{-1}$, and $98.9 \mathrm{~m}^{3} \mathrm{THB}^{-1}$ year ${ }^{-1}$, respectively. Meanwhile, the values of $0.27 \mathrm{~kg} \mathrm{CO}_{2} \mathrm{eq} \mathrm{THB}{ }^{-1}$ year $^{-1}, 3.48 \mathrm{~kg} \mathrm{Neq} \mathrm{THB}^{-1}$ year $^{-1}$, and $428.4 \mathrm{~m}^{3} \mathrm{THB}^{-1}$ year $^{-1}$ were generated in $\mathrm{CVF}$ for the $\mathrm{CF}, \mathrm{NF}$, and WF per net returns, respectively. Although our case study showed that OF generated lower values of $\mathrm{CF}, \mathrm{NF}$, and WF than in CVF, a larger number of field studies and long-term monitoring are needed for future studies.

Supplementary Materials: The following supporting information can be downloaded at: https: / /www.mdpi.com/article/10.3390/agronomy12020380/s1, S1: Greenhouse gas emission calculation; Table S1: Emissions factors used for calculation of GHG emissions from raw materials production phase; Table S2: Emissions factors used for calculation of GHG emissions from utilization phase.

Author Contributions: Conceptualization, N.A., S.S., W.C., C.W. and R.H.; methodology, N.A., S.S., W.C., C.W. and R.H.; investigation, N.A. and S.S.; writing-original draft preparation, N.A.; writingreview and editing, N.A.; supervision, W.C., C.W. and R.H. All authors have read and agreed to the published version of the manuscript.

Funding: This research project is supported by Mahidol University (Grant No. A14/2564). 
Institutional Review Board Statement: The study was conducted according to the guidelines of the Declaration of Helsinki, and approved by the Institutional Review Board of Institute for Population and Social Research, Mahidol University (IPSR-IRB) (COA. No. 2021/01-001).

Informed Consent Statement: Not applicable.

Data Availability Statement: Not applicable.

Acknowledgments: The authors extend their appreciation to Mahidol University (Grant No. A14/2564) for supporting research project. Moreover, the authors would like to thank National Research Council of Thailand (NRCT) (KO-BO-NGO/2557-68), the Biodiversity-based Economy Development Office (Public Organization) (BEDO) and National Research Council of Thailand (NRCT) (Grant No. 36/2561), and National Research Council of Thailand (NRCT) (Grant No. 205/2561) for providing the recorded data in their research projects.

Conflicts of Interest: The authors declare no conflict of interest.

\section{References}

1. Ciais, P.; Sabine, C.; Bala, G.; Bopp, L.; Brovkin, V.; Canadell, J.; Chhabra, A.; DeFries, R.; Galloway, J.; Heimann, M.; et al. Carbon and Other Biogeochemical Cycles. In Climate Change 2013: The Physical Science Basis; Stocker, T.F., Qin, D., Plattner, G.-K., Tignor, M., Allen, S.K., Boschung, J., Nauels, A., Xia, Y., Bex, V., Midgley, P.M., Eds.; Cambridge University Press: Cambridge, UK, 2013.

2. Field, C.B.; Barros, V.R. (Eds.) Climate Change 2014: Impacts, Adaptation and Vulnerability; Cambridge University Press: Cambridge, UK, 2014; p. 1820.

3. Office of Agricultural Economics (OAE). Agricultural Statistics of Thailand; Office of Agricultural Economics: Bangkok, Thailand, 2020. Available online: http://www.oae.go.th/assets/portals/1/files/jounal/2564/yearbook2563.pdf (accessed on 28 May 2021). (In Thai)

4. $\quad$ Ding, Y.; Liu, Y.X.; Wu, W.X.; Shi, D.Z.; Yang, M.; Zhong, Z.K. Evaluation of biochar effects on nitrogen retention and leaching in multi-layered soil columns. Water Air Soil Pollut. 2010, 213, 47-55. [CrossRef]

5. Pandey, D.; Agrawal, M. Carbon Footprint Estimation in the Agriculture Sector. In Assessment of Carbon Footprint in Different Industrial Sectors; Springer: Singapore, 2014; Volume 1, pp. 25-47.

6. Arunrat, N.; Wang, C.; Pumijumnong, N. Alternative cropping systems for greenhouse gases mitigation in rice field: A case study in Phichit province of Thailand. J. Clean. Prod. 2016, 133, 657-671. [CrossRef]

7. Maraseni, T.N.; Deo, R.C.; Qu, J.; Gentle, P.; Neupane, P.R. An international comparison of rice consumption behaviours and greenhouse gas emissions from rice production. J. Clean. Prod. 2018, 172, 2288-2300. [CrossRef]

8. Scialabba, N.E.-H.; Müller-Lindenlauf, M. Organic agriculture and climate change. Renew. Agric. Food Syst. 2010, 25, 158-169. [CrossRef]

9. Meena, A.L.; Pandey, R.N.; Kumar, D.; Dotaniya, M.L.; Sharma, V.K.; Singh, G.; Meena, B.P.; Kumar, A.; Bhanu, C. Impact of 12-year-long rice based organic farming on soil quality in terms of soil physical properties, available micronutrients and rice yield in a typic Ustochrept soil of India. Commun. Soil Sci. Plant Anal. 2020, 51(18), 2331-2348. [CrossRef]

10. Reganold, J.P.; Wachter, J.M. Organic agriculture in the twenty-first century. Nat. Plants 2016, 2, 15221. [CrossRef]

11. Meemken, E.M.; Qaim, M. Organic agriculture, food security, and the environment. Ann. Rev. Resour. Econ. 2018, 10, 39-63. [CrossRef]

12. Arunrat, N.; Sereenonchai, S.; Wang, C. Carbon footprint and predicting the impact of climate change on carbon sequestration ecosystem services of organic rice farming and conventional rice farming: A case study in Phichit province, Thailand. J. Environ. Manag. 2021, 289, 112458. [CrossRef]

13. Shahane, A.A.; Shivay, Y.S.; Prasanna, R.; Kumar, D. Improving water and nutrient use efficiency in rice by changing crop establishment methods, application of microbial inoculations, and Zn fertilization. Glob. Chall. 2019, 3, 1800005. [CrossRef]

14. Wiedmann, T.; Minx, J. A Definition of Carbon Footprint. Ecol. Econ. Res. Trends 2008, 1, 1-11.

15. Hoekstra, A.Y. 2003. Virtual Water Trade. In Proceedings of the International Expert Meeting on Virtual Water Trade, Delft, The Netherlands, 12-13 December 2002.

16. Hoekstra, A.Y.; Chapagain, A.K. Water footprints of nations: Water use by people as a function of their consumption pattern. Water Resour. Manag. 2010, 21, 35-48. [CrossRef]

17. Siebert, S.; Döll, P. Quantifying blue and green virtual water contents in global crop production as well as potential production losses without irrigation. J. Hydrol. 2010, 384, 198-207. [CrossRef]

18. Hoekstra, A.Y.; Chapagain, A.K.; Aldaya, M.M.; Mekonnen, M.M. The Water Footprint Assessment Manual: Setting the Global Standard; Earthscan: London, UK, 2011.

19. Hoekstra, A.Y.; Mekonnen, M.M. The water footprint of humanity. Proc. Natl. Acad. Sci. USA 2012, 109, 3232-3237. [CrossRef]

20. Gan, Y.; Liang, C.; Hamel, C.; Cutforth, H.; Wang, H. Strategies for reducing the carbon footprint of field crops for semiarid areas. A review. Agron. Sustain. Dev. 2011, 31, 643-656. [CrossRef]

21. Leach, A.M.; Galloway, J.N.; Bleeker, A.; Erisman, J.W.; Kohn, R.; Kitzes, J. A nitrogen Footprint model to help consumers understand their role in nitrogen losses to the environment. Environ. Dev. 2012, 1, 40-66. [CrossRef] 
22. Chen, Z.; Xu, C.; Ji, L.; Feng, J.; Li, F.; Zhou, X.; Fang, F. Effects of multi-cropping system on temporal and spatial distribution of carbon and nitrogen footprint of major crops in China. Glob. Ecol. Conserv. 2020, 22, e00895. [CrossRef]

23. Lal, R. Soil carbon sequestration to mitigate climate change. Geoderma 2004, 123, 1-22. [CrossRef]

24. Pan, G.; Li, L.; Wu, L.; Zhang, X. Storage and sequestration potential of topsoil organic carbon in China's paddy soils. Global Chang. Biol. 2004, 10, 79-92. [CrossRef]

25. Lu, F.; Wang, X.; Han, B.; Ouyang, Z.; Duan, X.; Zheng, H.; Miao, H. Soil carbon sequestrations by nitrogen fertilizer application, straw return and no-tillage in China's cropland. Glob. Chang. Biol. 2009, 15, 281-305. [CrossRef]

26. Buysse, P.; Roisin, C.; Aubinet, M. Fifty years of contrasted residue management of an agricultural crop: Impacts on the soil carbon budget and on soil heterotrophic respiration. Agri. Ecosyst. Environ. 2013, 167, 52-59. [CrossRef]

27. Arunrat, N.; Pumijumnong, N.; Sereenonchai, S.; Chareonwong, U.; Wang, C. Assessment of climate change impact on rice yield and water footprint of large-scale and individual farming in Thailand. Sci. Total Environ. 2020, 726, 137864. [CrossRef] [PubMed]

28. Wachter, J.M.; Reganold, J.P. Organic agricultural production: Plants. Encycl. Agr. Food Syst. 2014, 265-286.

29. Willer, H.; Schlatter, B.; Trávníček, J.; Kemper, L.; Lernoud, J. The World of Organic Agriculture—Statistics and Emerging Trends 2020; Research Institute of Organic Agriculture (FiBL): Frick, Switzerland; IFOAM-Organics International: Bonn, Germany, 2020.

30. Pongsrihadulchai, A. 2018. Thailand's Rice Industry and Current Policies Towards High Value Rice Products. In Proceedings of the International Seminar on Promoting Rice Farmers' Market Through Value-Adding Activities, Bangkok, Thailand, 6-7 June 2018; Food and Fertilizer Technology Center: Taipei, Taiwan. Available online: https:/ /ap.fftc.org.tw/article/1297 (accessed on 20 August 2021).

31. Ostle, N.J.; Levy, P.E.; Evans, C.D.; Smith, P. UK land use and soil carbon sequestration. Land Use Pol. 2009, 26, S274-S283. [CrossRef]

32. Gan, Y.; Liang, C.; Chai, Q.; Lemke, R.L.; Campbell, C.A.; Zentner, R.P. Improving farming practices reduces the carbon footprint of spring wheat production. Nat. Commun. 2014, 5, 5012. [CrossRef] [PubMed]

33. Adewale, C.; Reganold, J.P.; Higgins, S.; Evans, R.D.; Carpenter-Boggs, L. Improving carbon footprinting of agricultural systems: Boundaries, tiers, and organic farming. Environ. Impact Assess. Rev. 2018, 71, 41-48. [CrossRef]

34. Alam, M.K.; Bell, R.W.; Biswas, W.K. Decreasing the carbon footprint of an intensive rice-based cropping system using conservation agriculture on the Eastern Gangetic Plains. J. Clean. Prod. 2019, 218, 259-272. [CrossRef]

35. Richards, L.A. Diagnosis and Improvement of Saline and Alkali Soils. In Agriculture Handbook; United States Department of Agriculture: Washington, DC, USA, 1954.

36. National Soil Survey Center. Soil Survey Laboratory Methods Manual. In Soil Survey Investigations Report No. 42, Version 3.0; Natural Conservation Service: Washington, DC, USA, 1996.

37. Bray, R.A.; Kurtz, L.T. Determination of total organic and available form of phosphorus in soil. Soil Sci. 1945, 59, 39-45. [CrossRef]

38. Thomas, G.W. Method of Soil Analysis, Part 3: Chemical Methods. In Soil pH and Soil Acidity; Sparks, D.L., Page, A.L., Helmke, P.A., Loeppert, R.H., Soltanpour, P.N., Tabatabai, M.A., Johnston, C.T., Sumner, M.E., Eds.; ASA Inc.: Madison, WI, USA, 1996; pp. $475-490$.

39. Walkley, A.; Black, J.A. An examination of the dichromate method for determining soil organic matter and a proposed modification of the chromic acid titration method. Soil Sci. 1934, 37, 29-38. [CrossRef]

40. Ellert, B.H.; Bettany, J.R. Calculation of organic matter and nutrients stored in soils under contrasting management regimes. Can J. Soil Sci. 1995, 75, 529-538. [CrossRef]

41. IPCC (Intergovernmental Panel on Climate Change). 2019 Refinement to the 2006 IPCC Guidelines for National Greenhouse Gas Inventories; Calvo Buendia, E., Tanabe, K., Kranjc, A., Baasansuren, J., Fukuda, M., Ngarize, S., Osako, A., Pyrozhenko, Y., Shermanau, P., et al., Eds.; Intergovernmental Panel on Climate Change (IPCC): Geneva, Switzerland, 2019.

42. IPCC. Climate Change 2013: The Physical Science Basic Contribution of Working Group 1 to the Fifth Assessment Report of the Intergovernmental Panel on Climate Change; Cambridge University Press: Cambridge, UK, 2013.

43. The National Technical Committee on Product Carbon Footprinting. The National Guideline on Product Carbon Footprint, 3rd ed.; Amarin Publishing: Bangkok, Thailand, 2011.

44. TGO (Thailand Greenhouse Gas Management Organization). Product Category Rules (PCRS) of Rice in Thailand. 2014. Available online: http: / / thaicarbonlabel.tgo.or.th/PCR/A4.pdf (accessed on 20 September 2018).

45. EPA. Emission Factors for Greenhouse Gas Inventories; United States Environmental Protection Agency: Washington, DC, USA, 2014 Available online: https://www.epa.gov/sites/production/files/2015-07/documents/emission-factors_2014.pdf (accessed on 18 May 2016).

46. The National Technical Committee on Product Carbon Footprinting. National Guideline on Product National Guideline on Product Carbon Footprint; Amarin Publishing: Bangkok, Thailand, 2015.

47. Ecoinvent Centre. Ecoinvent Database v.3.2; Swiss Centre for Life Cycle Inventories: Duebendorf, Switzerland, 2015. Available online: http:/ / www.ecoinvent.org/ (accessed on 25 June 2016).

48. Maciel, V.G.; Zortea, R.B.; da Silva, W.M.; Cybis, L.F.A.; Einloft, S.; Seferin, M. Life Cycle Inventory for the agricultural stages of soybean production in the state of Rio Grande do Sul. Braz. J. Clean. Prod. 2015, 93, 65-74. [CrossRef]

49. Gu, B.; Leach, A.M.; Ma, L.; Galloway, J.N.; Chang, S.X.; Ge, Y. Nitrogen footprint in China: Food, energy, and nonfood goods. Environ. Sci. Technol. 2013, 47, 9217-9224. [CrossRef] [PubMed]

50. ISO 14044; Environmental Management e Life Cycle Assessment e Requirements and Guidelines; International Organization for Standardization: Geneva, Switzerland, 2006. 
51. Guinée, J.B.; Gorrée, M.; Heijungs, R.; Huppes, G.; Kleijn, R.; de Koning, A.; van Oers, L.; Wegener Sleeswijk, A.; Suh, S.; Udo de Haes, H.; et al. Life Cycle Assessment: An Operational Guide to the ISO Standards; Kluwer Academic Publishers: Dordrecht, The Netherlands, 2002.

52. Allan, J.A. Virtual water: A strategic resource global solutions to regional deficits. Ground Water 1998, 36, 545-546. [CrossRef]

53. Hoekstra, A.Y.; Hung, P.Q. Virtual water trade. A quantification of virtual water flows between nations in relation to international crop trade. Value Water Res. Rep. Ser. 2002, 11, 166.

54. Hoekstra, A.Y.; Chapagain, A.K. Globalization of Water: Sharing the Planet's Freshwater Resources; Blackwell Publishing: Oxford, UK, 2008.

55. Mekonnen, M.M.; Hoekstra, A.Y. Global gray water footprint and water pollution levels related to anthropogenic nitrogen loads to fresh water. Environ. Sci. Technol. 2015, 49, 12860-12868. [CrossRef] [PubMed]

56. Eggleston, H.S.; Buendia, L.; Miwa, K.; Ngara, T.; Tanabe, K. Agriculture, Forestry and Other Land Use. In IPCC Guidelines for National Greenhouse Gas Inventories; Institute for Global Environmental Strategies (IGES): Hayama, Japan, 2006.

57. Pollution Control Department. The Quality of Surface Water Standard; Ministry of Natural Resources and Environment: Bangkok, Thailand, 1994. (In Thai). Available online: http://infofile.pcd.go.th/law/3_14_water.pdf (accessed on 7 September 2019).

58. Yang, X.; Gao, W.; Zhang, M.; Chen, Y.; Sui, P. Reducing agricultural carbon footprint through diversified crop rotation systems in the North China Plain. J. Clean. Prod. 2014, 76, 131-139. [CrossRef]

59. Wang, L.; Li, L.; Xie, J.; Luo, Z.; Zhang, R.; Cai, L.; Coulter, J.A.; Palta, J.A. Managing the trade-offs among yield, economic benefits and carbon and nitrogen footprints of wheat cropping in a semi-arid region of China. Sci. Total Environ. 2021, 768, 145280. [CrossRef]

60. Bennett, M.; Franzell, S. Can organic and resource-conserving agriculture improve livelihood. Int. J. Agric. Sustain. 2013, 11, 193-215. [CrossRef]

61. Sun, M.; Xiao, T.; Ning, Z.; Xiao, E.; Sun, W. Microbial community analysis in rice paddy soils irrigated by acid mine drainage contaminated water. Appl. Microbiol. Biotechnol. 2015, 99, 2911-2922. [CrossRef]

62. Pahalvi, H.N.; Rafiya, L.; Rashid, S.; Nisar, B.; Kamili, A.N. Chemical Fertilizers and Their Impact on Soil Health. Microbiota Biofertil. 2021, 2, 1-20.

63. Lin, W.; Lin, M.; Zhou, H.; Wu, H.; Li, Z.; Lin, W. The effects of chemical and organic fertilizer usage on rhizosphere soil in tea orchards. PLoS ONE 2019, 14, e0217018. [CrossRef]

64. Rukshana, F.; Butterly, C.R.; Xu, J.-M.; Baldock, J.A.; Tang, C. Organic anion-to- acid ratio influences pH change of soils differing in initial pH. Int. J. Soil Sediment Water 2013, 14, 407-414. [CrossRef]

65. Gathala, M.K.; Ladha, J.K.; Saharawat, Y.S.; Kumar, V.; Kumar, V.; Sharma, P.K. Effect of tillage and crop establishment methods on physical properties of a medium-textured soil under a seven-year Rice-Wheat rotation. Soil Sci. Soc. Am. J. 2011, 75, 1851-1862. [CrossRef]

66. Gelybó, G.; Tóth, E.; Farkas, C.; Horel, A.; Kása, I.; Bakacsi, Z. Potential impacts of climate change on soil properties. Agrokem. Talajt. 2018, 67, 121-141. [CrossRef]

67. Jat, H.S.; Datta, A.; Sharma, P.C.; Kumar, V.; Yadav, A.K.; Choudhary, M.; Choudhary, V.; Gathala, M.K.; Sharma, D.K.; Jat, M.L.; et al. Assessing soil properties and nutrient availability under conservation agriculture practices in a reclaimed sodic soil in cereal-based systems of North-West India. Arch. Agron. Soil Sci. 2018, 64, 531-545. [CrossRef] [PubMed]

68. Dai, H.; Chen, Y.; Yang, X.; Cui, J.; Sui, P. The effect of different organic materials amendment on soil bacteria communities in barren sandy loam soil. Environ. Sci. Pollut. Res. 2017, 24, 24019-24028. [CrossRef]

69. Hiederer, R.; Köchy, M. Global Soil Organic Carbon Estimates and the Harmonized World Soil Database; Publication Office of the European Union: Brussels, Belgium, 2011. Available online: https://esdac.jrc.ec.europa.eu/ESDB_Archive/eusoils_docs/Other/ EUR25225.pdf (accessed on 2 July 2021).

70. Zdruli, P.; Lal, R.; Cherlet, M.; Kapur, S. New World Atlas of Desertification and Issues of Carbon Sequestration, Organic Carbon Stocks, Nutrient Depletion and Implications for Food Security. In Carbon Management, Technologies, and Trends in Mediterranean Ecosystems; Erşahin, S., Kapur, S., Akça, E., Naml1, A., Erdoğan, H.E., Eds.; Springer: Cham, Switzerland, 2017 ; pp. 13-25.

71. Adamu, H.; Umar, Y.A.; Akanang, H.; Sabo, A. Evaluation of Carbon Sequestration Potential of Soils-What Is Missing? J. Geosci. Environ. Prot. 2021, 9, 39-47. [CrossRef]

72. Pan, G.; Xu, X.; Smith, P.; Pan, W.; Lal, R. An increase in topsoil SOC stock of China's croplands between 1985 and 2006 revealed by soil monitoring. Agr. Ecosyst. Environ. 2010, 136, 133-138. [CrossRef]

73. Freibauer, A.; Rounsevell, M.D.A.; Smith, P.; Verhagen, J. Carbon sequestration in agricultural soils of Europe. Geoderma 2004, 122, 1-23. [CrossRef]

74. Knudsen, M.T.; Meyer-Aurich, A.; Olesen, J.E.; Chirinda, N.; Hermansen, J.E. Carbon footprints of crops from organic and conventional arable crop rotationse using a life cycle assessment approach. J. Clean. Prod. 2014, 64, 609-618. [CrossRef]

75. Ghimire, R.; Lamichhane, S.; Acharya, B.S.; Bista, P.; Sainju, U.M. Tillage, crop residue, and nutrient management effects on soil organic carbon in rice-based cropping systems: A review. J. Integr. Agric. 2017, 16, 1-15. [CrossRef]

76. Smith, P. Soil Organic Carbon Dynamics and Land-Use Change. In Land Use and Soil Resources; Braimoh, A.K., Vlek, P.L.G., Eds.; Springer: Dordrecht, The Netherlands, 2008; pp. 9-22.

77. Paustian, K.; Andrén, O.; Janzen, H.H.; Lal, R.; Smith, P.; Tian, G.; Tiessen, H.; van Noordwijk, M.; Woomer, P.L. Agricultural soils as a sink to mitigate $\mathrm{CO}_{2}$ emissions. Soil Use Manag. 1997, 13, 229-244. [CrossRef] 
78. IPCC. Guidelines for National Greenhouse Gas Inventories: Workbook (Revised 1996); Intergovernmental Panel on Climate Change: Paris, France, 1997.

79. Smith, P.; Powlson, D.S. Sustainability of soil management practices: A global perspective. In Soil Biological Fertility: A Key to Sustainable Land Use in Agriculture; Abbott, L.K., Murphy, D.V., Eds.; Kluwer Academic Publishers: Dodrecht, The Netherlands, 2003; pp. 241-254.

80. Mohammadi, A.; Omid, M. Economical analysis and relation between energy inputs and yield of greenhouse cucumber production in Iran. Appl. Energy 2010, 87, 191-196. [CrossRef]

81. Banaeian, N.; Namdari, M. Effect of ownership energy use efficiency in watermelon farms-A data envelopment analysis approach. Int. J. Renew. Energy Res. 2011, 1, 75-82.

82. Khoshnevisan, B.; Rafiee, S.; Omid, M.; Mousazadeh, H. Reduction of $\mathrm{CO}_{2}$ emission by improving energy use efficiency of greenhouse cucumber production using DEA approach. Energy 2013, 55, 676-682. [CrossRef]

83. Zhang, W.; Dou, Z.; He, P.; Ju, X.; Powlson, D.; Chadwick, D.; Norse, D.; Lu, Y.; Zhang, Y.; Wu, L. New technologies reduce greenhouse gas emissions from nitrogenous fertilizer in China. Proc. Natl. Acad. Sci. USA 2013, 110, 8375-8380. [CrossRef]

84. Dubey, S.K. Methane emission and rice agriculture. Curr. Sci. 2001, 81, 345-346.

85. Yu, K.; Böhme, F.; Rinklebe, J.; Neue, H.U.; Delaune, R.D. Major biogeochemical processes in soils-a microcosm incubation from reducing to oxidizing conditions. Soil Sci. Soc. Am. J. 2007, 71, 1406-1417. [CrossRef]

86. Yan, X.; Akiyama, H.; Yagi, K.; Akimoto, H. Global estimations of the inventory and mitigation potential of methane emissions from rice cultivation conducted using the 2006 Intergovernmental Panel on Climate Change Guidelines. Glob. Biogeochem. Cycles 2009, 23, GB2002. [CrossRef]

87. Alam, M.K.; Biswas, W.K.; Bell, R.W. Greenhouse gas implications of novel and conventional rice production technologies in the Eastern-Gangetic plains. J. Clean. Prod. 2016, 112, 3977-3987. [CrossRef]

88. Bacenetti, J.; Fusi, A.; Negri, M.; Fiala, M. Impact of cropping system and soil tillage on environmental performance of cereal silage productions. J. Clean. Prod. 2015, 86, 49-59. [CrossRef]

89. Kanter, D.R.; Searchinger, T.D. A technology-forcing approach to reduce nitrogen pollution. Nat. Sustain. 2018, 1, 544-552. [CrossRef]

90. Fan, D.J.; Zhang, H.R.; Liu, T.Q.; Cougui, C.; Chengfeng, L. Control effects of Chelonus munakatae against Chilo suppressalis and impact on greenhouse gas emissions from paddy fields. Front. Plant Sci. 2020, 11, 228. [CrossRef] [PubMed]

91. Arunrat, N.; Pumijumnong, N. Practices for reducing greenhouse gas emissions from rice production in Northeast Thailand. Agriculture $2017,7,4$.

92. Champrasert, P.; Sampattagul, S.; Yodkhum, S.; Wangpakapattanawong, P. Assessment of carbon footprint of upland rice production in Northern Thailand. CMU J. Nat. Sci. 2020, 19, 427-446. [CrossRef]

93. Thanawong, K.; Perret, S.R.; Basset-Mens, C. Eco-efficiency of paddy rice production in Northeastern Thailand: A comparison of rain-fed and irrigated cropping systems. J. Clean. Prod. 2014, 73, 204-217. [CrossRef]

94. Yodkhum, S.; Gheewala, S.H.; Sampattagul, S. Life cycle GHG evaluation of organic rice production in northern Thailand. J. Environ. Manag. 2017, 196, 217-223. [CrossRef]

95. Yodkhum, S.; Sampattagul, S.; Gheewala, S.H. Energy and environmental impact analysis of rice cultivation and straw management in northern Thailand. Environ. Sci. Pollut. Res. 2018, 25, 17654-17664. [CrossRef]

96. Mungkung, R.; Sitthikitpanya, S.; Dangsiri, S.; Gheewala, S.H. Life cycle assessment of Thai Hom Mali rice to support the policy decision on organic farming area expansion. Sustainability 2020, 12, 6003. [CrossRef]

97. Petersen, B.M.; Knudsen, M.T.; Hermansen, J.E.; Halberg, N. An approach to include soil carbon changes in life cycle assessments. J. Clean. Prod. 2013, 52, 217-224. [CrossRef]

98. Goglio, P.; Smith, W.N.; Grant, B.B.; Desjardins, R.L.; McConkey, B.G.; Campbell, C.A.; Nemecek, T. Accounting for soil carbon changes in agricultural life cycle assessment (LCA): A review. J. Clean. Prod. 2015, 104, 23-39. [CrossRef]

99. Alam, M.K.; Bell, R.W.; Haque, M.E.; Kader, M.A. Minimal soil disturbance and increased residue retention increase soil carbon in rice-based cropping systems on the Eastern Gangetic Plain. Soil Till. Res. 2018, 183, 28-41. [CrossRef]

100. Jiang, Z.H.; Zhong, Y.M.; Yang, J.P.; Wu, Y.X.Y.; Hui, L.; Zheng, L. Effect of nitrogen fertilizer rates on carbon footprint and ecosystem service of carbon sequestration in rice production. Sci. Total Environ. 2019, 670, 210-217. [CrossRef] [PubMed]

101. Wang, X.H.; Yang, H.S.; Liu, J.; Wu, J.; Chen, W.; Wu, J.; Zhu, L.; Bian, X. Effects of ditch-buried straw return on soil organic carbon and rice yields in a rice-wheat rotation system. Catena 2015, 127, 56-63. [CrossRef]

102. Zhang, J.; Bei, S.; Li, B.; Zhang, J.; Christie, P.; Li, X. Organic fertilizer, but not heavy liming, enhances banana biomass, increases soil organic carbon and modifies soil microbiota. Appl. Soil Ecol. 2019, 136, 67-79. [CrossRef]

103. Xue, X.B.; Landis, A.E. Eutrophication potential of food consumption patterns. Environ. Sci. Technol. 2010, 44, 6450-6456. [CrossRef] [PubMed]

104. Pierer, M.; Winiwarter, W.; Leach, A.M.; Galloway, J.N. The nitrogen footprint of food products and general consumption patterns in Austria. Food Policy 2014, 49, 128-136. [CrossRef]

105. Xue, J.F.; Pu, C.; Liu, S.L. Carbon and nitrogen footprint of double rice production in Southern China. Ecol. Indicat. 2016, 64, 249-257. [CrossRef]

106. Chen, X.; Cui, Z.; Fan, M.; Vitousek, P.; Zhao, M.; Ma, W.; Wang, Z.; Zhang, W.; Yan, X.; Yang, J. Producing more grain with lower environmental costs. Nature 2014, 514, 486-489. [CrossRef] 
107. Chapagain, A.K.; Hoekstra, A.Y. The Green, Blue and Grey Water Footprint of Rice from Both a Production and Consumption Perspective. In Value of Water Research Report Series No. 40; IHE Institute for Water Education: Delft, The Netherlands, 2010.

108. Johannes, H.P.; Priadi, C.R.; Herdiansyah, H.; Novalia, I. Water Footprint Saving through Organic Rice Commodity; AIP Publishing: College Park, MD, USA, 2020.

109. Galloway, J.N.; Cowling, E.B. Reactive nitrogen and the world: 200 years of change. Ambio 2002, 31, 64-71. [CrossRef]

110. Benbi, D.K. Carbon footprint and agricultural sustainability nexus in an intensively cultivated region of Indo-Gangetic Plains. Sci. Total Environ. 2018, 644, 611-623. [CrossRef]

111. Thirkell, T.J.; Charters, M.D.; Elliott, A.J.; Sait, S.M.; Field, K.J. Are mycorrhizal fungi our sustainable saviours? Considerations for achieving food security. J. Ecol. 2017, 105, 921-929. [CrossRef] 